\title{
Diplodus levantinus (Teleostei: Sparidae), a new species of sea bream from the southeastern Mediterranean Sea of Israel, with a checklist and a key to the species of the Diplodus sargus species group
}

\author{
Ronald Fricke ${ }^{1,2}$, Daniel Golani ${ }^{3}$, Brenda Appelbaum-Golani ${ }^{4}$ \\ ${ }^{1}$ Im Ramstal 76, 97922 Lauda-Königshofen, Germany. E-mail: ronfricke@web.de \\ ${ }^{2}$ Staatliches Museum für Naturkunde Stuttgart, Rosenstein 1, 70191 Stuttgart, Germany [temporarily out of office]. \\ ${ }^{3}$ National Natural History Collections and Department of Ecology, Evolution and Behavior, The Hebrew University of \\ Jerusalem, 91904 Jerusalem, Israel. E-mail: dani.golani@mail.huji.ac.il \\ ${ }^{4}$ Mt. Scopus Library, The Hebrew University of Jerusalem, 91905 Jerusalem, Israel. E-mail: brendag@ savion.huji.ac.il
}

\begin{abstract}
Summary: The sea bream Diplodus levantinus n. sp. is described from off the coasts of Israel in the eastern Mediterranean Sea, where it replaces Diplodus sargus (Linnaeus, 1758). The new species is characterized by 11-12 spines and 10-16 soft rays in the dorsal fin, 3 spines and 11-13 soft rays in the anal fin, 15-17 pectoral fin rays, 6-9 + 8-12 gill rakers on the first gill arch, upper and lower jaws with a single row of 4 incisors on each side, followed by a total of 16-19 molariform teeth in the upper jaw and 12-14 molariform teeth in the lower jaw, with the molariforms of the upper jaw separated from the incisors by a wide, toothless gap, and the sides of the body in adults with 8 vertical bars of equal width which are present even in large adults, followed by a broad bar on the caudal peduncle which usually nearly reaches the ventral margin of the caudal peduncle. An updated checklist of the species of the genus Diplodus, and a key to species of the Diplodus sargus species group from the eastern Atlantic and Mediterranean Sea, are presented.
\end{abstract}

Keywords: taxonomy; fishes; new species; Mediterranean Sea; neotype designation; checklist; key.

Diplodus levantinus (Teleostei: Sparidae), una nueva especie de sargo del Mediterráneo sudeste frente a Israel, con una lista de especies y una clave de clasificación de las especies del grupo Diplodus sargus

Resumen: El sargo levantino Diplodus levantinus n. sp. se describe a partir de ejemplares de las costas de Israel, en el Mediterráneo oriental, donde reemplaza a Diplodus sargus (Linnaeus, 1758). La nueva especie se caracteriza por: 11-12 espinas y 10-16 radios blandos en la aleta dorsal, 3 espinas y 11-13 radios blandos en la aleta anal, 15-17 radios en las pectorales, 6-9 + 8-12 branquispinas en el primer arco branquial; las mandíbulas superior e inferior con una sola fila de 4 incisivos en cada lado, seguidos por un total de 16-19 molares en la mandíbula superior y 12-14 molares en la mandíbula inferior, con los molares de la mandíbula superior separados de los incisivos por una gran distancia sin dientes; los lados del cuerpo, en los adultos, con 8 bandas verticales de igual anchura, presentes incluso en adultos de gran tamaño, seguidas de una amplia banda en el pedúnculo caudal que, por lo general, casi alcanza el margen ventral del pedúnculo caudal. Se diferencia principalmente de D. sargus por el menor número de dientes molares en las mandíbulas superior e inferior, y por la amplia separación, sin dientes, entre molares e incisivos de la mandíbula superior. Se presenta una lista actualizada de las especies del género Diplodus y una clave para las especies del grupo de especies Diplodus sargus del Atlántico este y el Mediterráneo.

Palabras clave: taxonomía; peces; nueva especie; mar Mediterráneo; designación de neotipo; lista de especies; clave.

Citation/Como citar este artículo: Fricke R, Golani D, Appelbaum-Golani B. 2016. Diplodus levantinus (Teleostei: Sparidae), a new species of sea bream from the southeastern Mediterranean Sea of Israel, with a checklist and a key to the species of the Diplodus sargus species group. Sci. Mar. 80(3): 305-320. doi: http://dx.doi.org/10.3989/scimar.04414.22B

LSID: urn:lsid:zoobank.org:pub:593EC0BD-AC53-4A43-AC0D-5C1FD44B98CC

Editor: M.P. Olivar.

Received: February 2, 2016. Accepted: April 4, 2016. Published: July 1, 2016.

Copyright: () 2016 CSIC. This is an open-access article distributed under the terms of the Creative Commons Attribution (CC-by) Spain 3.0 License. 


\section{INTRODUCTION}

The sparid fish genus Diplodus are distributed in tropical and warm temperate waters of the Atlantic Ocean and the western Indian Ocean including the Red Sea. They are mainly found on shallow water reefs. The genus includes a total of 22 valid subspecies and species (Paz et al. 1974, Paz 1982, Eschmeyer and Fricke 2015).

Diplodus was first described by Rafinesque (1810a: $26,54)$ for Sparus annularis Linnaeus, 1758. The species of the genus have been known since ancient times; two species now assigned to the genus were described by Linnaeus (1758), namely Diplodus annularis and D. sargus. The latter species has been known since Aristotle, and its description by Linnaeus (1758) was based on multiple sources from localities in the Mediterranean Sea (Greece, France, Italy). Valenciennes in Cuvier and Valenciennes (1830: 14) unnecessarily renamed the species as Sargus rondeletii, a name that was used by many subsequent authors. Diplodus sargus may reach a total length of up to $40 \mathrm{~cm}$ (ManWai and Quignard 1982: 175), which equals a standard length of approximately $324 \mathrm{~mm}$; Fischer et al. (1987) even give a maximum total length of $45 \mathrm{~cm}$. Cadenat (1964) revised the genus Diplodus from West Africa, and revived the name Diplodus sargus; he described two subspecies, including the description of Diplodus sargus typicus, which included specimens from West Africa as well as the Mediterranean Sea. Partially based on his West African material, Paz et al. (1974) described a new subspecies Diplodus sargus cadenati from West Africa and the Canary Islands.

In his thesis project, Paz (1975) revised the genus Diplodus. He defined the Diplodus sargus species group as having 4-10 vertical bands along the sides of the body, plus sometimes additional smaller bands in the spaces between the main bands, 4 incisors each in the upper and lower jaws, and large molars in 2-4 rows. In the species group, he included the subspecies Diplodus sargus sargus (Linnaeus, 1758) from the Mediterranean, D. s. cadenati Paz, Bauchot and Daget, 1974 from the eastern Atlantic, D. s. capensis (Smith, 1844) from South Africa, and D. s. lineatus (Valenciennes in Cuvier and Valenciennes, 1830) from the Cape Verde Islands. These results were previously summarized in the paper of Paz et al. (1974). In addition, he reported "Diplodus X" from Israel (Paz 1975: 57-61, Fig. 27), which he thought to be a questionable hybrid between D. sargus and D. annulatus. Paz (1982) expanded the Diplodus sargus species group to include two additional subspecies from the South Atlantic, four from the western Atlantic, and two from the Indian Ocean. The suspected hybrid status of the population in Israel was not mentioned again in this paper or in subsequent literature.

When we examined specimens of Diplodus from Israel, our attention was drawn to the identity of specimens previously named Diplodus sargus (non Linnaeus, 1758), which were found to be distinct from "typical" Diplodus sargus from other parts of the Mediterranean Sea. The analysis of these individuals demonstrated that the population from Israel represents a separate species, which is described in the present paper.

\section{MATERIALS AND METHODS}

Specimens were examined at the Academy of Natural Sciences of Philadelphia (ANSP); Hebrew University, Jerusalem (HUJ); Muséum National d'Histoire Naturelle, Paris (MNHN); Museo Civico di Storia Naturale "Giacomo Doria", Genoa, Italy (MSNG); Staatliches Museum für Naturkunde, Stuttgart (SMNS); National Museum of Natural History, Washington, D.C. (USNM); and Museum für Naturkunde der Humboldt- Universität, Berlin (ZMB).

Descriptive methods follow Caldwell (1965). Proportional measurements and counts for the holotype of Diplodus levantinus n. sp. are given first, followed by those of the paratypes in parentheses. Following the method of Fricke et al. (2007), subspecies are no longer used: they are either raised to the species level or synonymized. The classification is based on Eschmeyer and Fricke (2015) and references follow Fricke (2015). The museum abbreviations follow Fricke and Eschmeyer (2015).

Comparative material: Diplodus annularis: HUJ 7149 (5, Haifa, Israel); HUJ 7814 (2, Jaffa, Israel); HUJ 9616 (1, Bardawil Lagoon, Egypt); HUJ 9757 (1, Jaffa, Israel); HUJ 12237 (1, Haifa, Israel); HUJ 18383 (1, Haifa, Israel); HUJ 19056 (2, Istanbul, Turkey); SMNS 995 (3, Italy, Trieste); SMNS 1009 (1, France Nice); SMNS 4808 (1, France, Alpes Maritimes); SMNS 9184 (1, Croatia, Istria); SMNS 9183 (2, Italy, Genova); SMNS 9188 (1, Italy, Genova); SMNS 9438 (1, Croatia, Cres Island); SMNS 9591 (1, Greece, Varkisa); SMNS 9629 (1, Greece, Varkisa); SMNS 9868 (1, Greece, Varkisa); SMNS 11186 (1, Greece, Gulf of Laconia); SMNS 11539 (2, Turkey, Muğla); SMNS 11597 (2, Greece, Varkisa); SMNS 12478 (1, Spain, Balearic Islands, Formentera); SMNS 15770 (1, Italy, Sardinia); SMNS 23470 (1, Canary Islands, El Hierro); SMNS 23474 (1, Canary Islands, El Hierro); SMNS 23478 (1, Canary Islands, El Hierro); SMNS 23490 (1, Canary Islands, El Hierro); SMNS 24260 (1, Canary Islands, Tenerife); SMNS 24294 (3, Canary Islands, Tenerife); SMNS 24299 (1, Spain, Cadiz); SMNS 24308 (1, Spain, Cadiz); SMNS 25294 (4, Turkey, Antalya); SMNS 25735 (2, Italy, Venice); SMNS 25736 (1, Monaco): ZMB 33511 (1, Turkey, Alanya). Diplodus argenteus: MSNG 40167 (1, USA, Florida); MSNG 42500 (1, Uruguay, Montevideo); MSNG 43730 (2, Uruguay, Montevideo); USNM 375532 (1, Brazil, Santa Catarina); USNM 384179 (1, Brazil, Santa Catarina). Diplodus ascensionis: ANSP 158788 (1, Ascension Island). Diplodus bellottii: SMNS 10301 (3, Canary Islands, Lanzarote); SMNS 16722 (2, Canary Islands, Fuerteventura); ZMB 33614 (1, Western Sahara). Diplodus bermudensis: USNM 351263 (1, Bermuda). Diplodus cadenati: HUJ 19258 (1, Canary Islands, Tenerife); HUJ 20532 (2 jaws, Canary Islands, Tenerife); HUJ 20533 (3 jaws, Canary Islands, Tenerife); HUJ 20534 (3 jaws, Senegal, Dakar); MSNG 42382 (1, Canary Islands); MSNG 42885 (1, Portugal, Sesimbra); SMNS 11921 (1, Senegal, Dakar); SMNS 16738 (1, Canary Islands, Fuerteventura); ZMB 13819 (1, Azores); ZMB 13833 (2, Azores); ZMB 19185 (2, Azores, São Miguel). Diplodus capensis: MSNG 26649 (2, South Africa, Cape Province); SMNS 25672 (1, South Africa); ZMB 1071 (1, South Africa, Cape Province); ZMB 1072 (1, South Africa, Cape Province). Diplodus caudimacula: USNM 53152 (1, Bahamas, New Providence); USNM 123128 (1, Venezuela, Estanques Bay). Diplodus cervinus: HUJ 14171 (3, Bardawil Lagoon, Egypt); HUJ 18928 (2, Mikhmoret, Israel); MSNG 13110 (1, Canary Islands, Tenerife); MSNG 13112 (1, Italy, Palermo); MSNG 39819 (1, Italy, Genoa); SMNS 10329 (1, Canary Islands, Lanzarote); SMNS 10355 (2, Canary Islands, Lanzarote); SMNS 11791 (1, Canary Islands, Gomera); SMNS 16779 (1, Canary Islands, Fuerteventura); SMNS 24310 (6, Spain, Cadiz). Diplodus fasciatus: HUJ 20369 (2 jaws, Cape Verde Islads, Boa Vista); MSNG 13111 (2, Cape 
Verde Islands). Diplodus helenae: USNM 384180 (2, Saint Helena Island) Diplodus holbrookii: USNM 416496 (1, USA, Florida): USNM 416810 (1, USA, Florida). Diplodus hottentotus: SMNS 25729 (South Africa, Cape Province). Diplodus kotschyi: SMNS 14426 (1, Iraq, Persian/Arabian Gulf, Fao). Diplodus lineatus: HUJ 20368 (2 jaws, Cape Verde Islands, Boa Vista); SMNS 21984 (2, Cape Verde Islands, Sao Tiago); SMNS 26374 (1, Cape Verde Islands, Sao Tiago). Diplodus noct: HUJ 4314 (3, Egypt, Red Sea, Abu Zenima); HUJ 4314 (5, Egypt, Red Sea, Ras Mohammad); HUJ 4316 (5, Egypt, Red Sea, Et-Tur); HUJ 6375 (5, Israel, Red Sea, Eilat); HUJ 10082 (5, Egypt, Red Sea, Et-Tur); HUJ 10105 (1, Egypt, Red Sea, Ras Sudar); HUJ 20154 (1, Israel, Red Sea, Eilat); MSNG 40243 (1, Egypt, Hurghada; MSNG 40573 (5, Israel, Eilat); SMNS 245 (1, Egypt, Red Sea, Port Safaga); SMNS 253 (1, Egypt, Red Sea, Port Safaga); SMNS 2062 (2, Egypt, Red Sea, Al-Qusayr); SMNS 3509 (1, Egypt, Red Sea, Al-Qusayr); SMNS 4630 (1, Egypt, Red Sea, Suez); SMNS 5132 (1, Red Sea); SMNS 8450 (3, Israel, Red Sea, Gulf of Aqaba); SMNS 14338 (15, Israel, Red Sea, Gulf of Aqaba); ZMB 375-376 (7, Red Sea); ZMB 9284 (1, Egypt, Red Sea, Suez); ZMB 19994 (1, Egypt, Red Sea, Et-Tur); ZMB 23165 (1, Yemen, Red Sea, Al-Hudaida). Diplodus omanensis: MNHN 1984-0359 (1 paratype, Oman). Diplodus prayensis: HUJ 20370 (1 jaw, Cape Verde Islands, Boa Vista); SMNS 21983 (2, Cape Verde Islands, Sao Tiago). Diplodus puntazzo: HUJ 7380 (1, Haifa, Israel); MSNG 49324 (1, Italy, Livorno); MSNG 49363 (1, Italy, Livorno); MSNG 49832 (4, Italy, Livorno); SMNS 970 (1, Italy, Trieste); SMNS 1288 (1, Italy, Trieste); SMNS 2173 (1, Italy); SMNS 12659 (2, Italy, Sicily); SMNS 15295 (2, Canary Islands, La Palma); SMNS 15301 (1, Canary Islands, La Palma) SMNS 15310 (1, Canary Islands, La Palma); SMNS 15335 (2, Canary Islands, La Palma). Diplodus sargus: HUJ 5600 (1, Cyprus); HUJ 6047 (1, $64.3 \mathrm{~mm}$ SL, neotype of Sargus raucus Geoffroy Saint-Hilaire 1809 as designated below, Egypt, Bardawil Lagoon); HUJ 6057 (1, Egypt, Bardawil Lagoon); HUJ 20541 (2, Greece, Rhodes Island); HUJ 20274 (1, Greece, Rhodos Island); HUJ 20542 (2 jaws, France, Marseille); MSNG 13105 (2, Adriatic Sea, Croatia, Vis Island); MSNG 37625 (5, Italy, Naples); MSNG 41046 (1, Black Sea, Romania, Agigea); MSNG 42046 (2, Italy, Messina); MSNG 42430 (1, Italy, Giglio Island); MSNG 42678 (2, Italy, Livorno); MSNG 49327 (4, Italy, Livorno); MSNG 49364 (3, Italy, Livorno); MSNG 49383 (2, Italy, Livorno); MSNG 49944 (1, Italy, Genoa); MSNG 51835 (1, Adriatic Sea, Italy, Piceno); MSNG 52095 (4, Adriatic Sea, Italy, Piceno); SMNS 1016 (1, France, Nice); SMNS 9153 (2, Croatia, Istria); SMNS 16714 (1, Croatia, Cres Island); SMNS 17916 (1, Turkey, Alanya); SMNS 19065 (17, Northern Cyprus, west of Girne); SMNS 19072 (5, Northern Cyprus, W of Girne); SMNS 19083 (1, Northern Cyprus, W of Girne); SMNS 25309 (2, Tur- key, Muğla); SMNS 25310 (2, Turkey, Muğla); ZMB 1055 (1, Egypt, Alexandria); ZMB 1056 (1, Italy, Trieste); ZMB 18583 (2, Croatia, Rovinj); ZMB 19965 (2, Croatia, Rovinj). Diplodus striatus: SMNS 17102 (1, Rodrigues Island). Diplodus vulgaris: HUJ 10736 (1, Haifa, Israel); HUJ 12362 (1, Akko, Israel); HUJ 14020 (8, Bardawil Lagoon, Egypt); HUJ 20281 (1, Jaffa, Israel); MSNG 13102 (10, Croatia, Dalmatia); MSNG 42028 (2, Italy, Livorno); MSNG 42050 (3, Italy, Messina); MSNG 42982 (1, Greece, Ionian Islands); MSNG 43669 (3. Italy, Messina; MSNG 48266 (2, Italy, Arenzano); MSNG 49312 (4, Italy, Livorno); MSNG 49362 (4, Italy, Livorno); MSNG 49615 (1, Italy, Genoa); MSNG 49833 (10, Italy, Livorno); MSNG 51831 (2, Adriatic Sea, Italy, Piceno); MSNG 52091 (2, Adriatic Sea, Italy, Piceno); SMNS 1054 (1, France, Nice); SMNS 9128 (1, Spain, Balearic Islands, Mallorca); SMNS 9131 (1, Croatia, Istria); SMNS 9410 (1, Spain, Balearic Islands, Menorca); SMNS 9437 (1, Croatia, Cres Island); SMNS 9607 (1, Greece, Varkisa); SMNS 9616 (1, Greece, Varkisa); SMNS 10319 (1, Canary Islands, Lanzarote); SMNS 11537 (1, Turkey, Muğla); SMNS 12477 (1, Spain, Balearic Islands, Formentera); SMNS 15742 (1, Greece, Sithonia); SMNS 16745 (1, Canary Islands, Fuerteventura); SMNS 19084 (1, Northern Cyprus, west of Girne); SMNS 20349 (1, Tunisia, Tabarka); SMNS 20377 (1, Tunisia, Tabarka); SMNS 21342 (1, Italy, Ischia Island); SMNS 25293 (1, Turkey, Prov. Antalya).

\section{TAXONOMY}

\section{Diplodus levantinus new species} (Figs 1-4, Table 1)

Sargus Rondeletii (non Valenciennes in Cuvier and Valenciennes, 1830): Steinitz 1927: 338 (Haifa, Israel).

Sargus sargus (non Linnaeus, 1758): Liebman 1934: 323 (Palestine/ Israel; most frequent and abundant species).

Diplodus sargus (non Linnaeus, 1758): Hornell 1935: 83 (Palestine/ Israel). Bodenheimer 1937: 273 (Palestine/Israel). Ben-Tuvia 1953a: 23 (Israel, common along the shores). Ben-Tuvia 1953b: 439 (off Caesarea, Israel). Ben-Tuvia 1971: 32 (Israel). Golani 1996: 39 (Israel). Golani 2005: 43 (Israel). Golani 2006: 182183 (Israel). Golani et al. 2006: 163.

Sargus rondeletti (non Valenciennes in Cuvier and Valenciennes, 1830): Bodenheimer 1935: 462 (Palestine/Israel)

Diplodus X (probably a hybrid of Diplodus annularis $\times$ Diplodus sargus): Paz et al. 1974: 126. Paz 1975: 57-61 (Tantura Bay, Israel).

Diplodus sargus sargus (non Linnaeus, 1758): Whitehead et al. 1986: 894-895 (part: Israel).

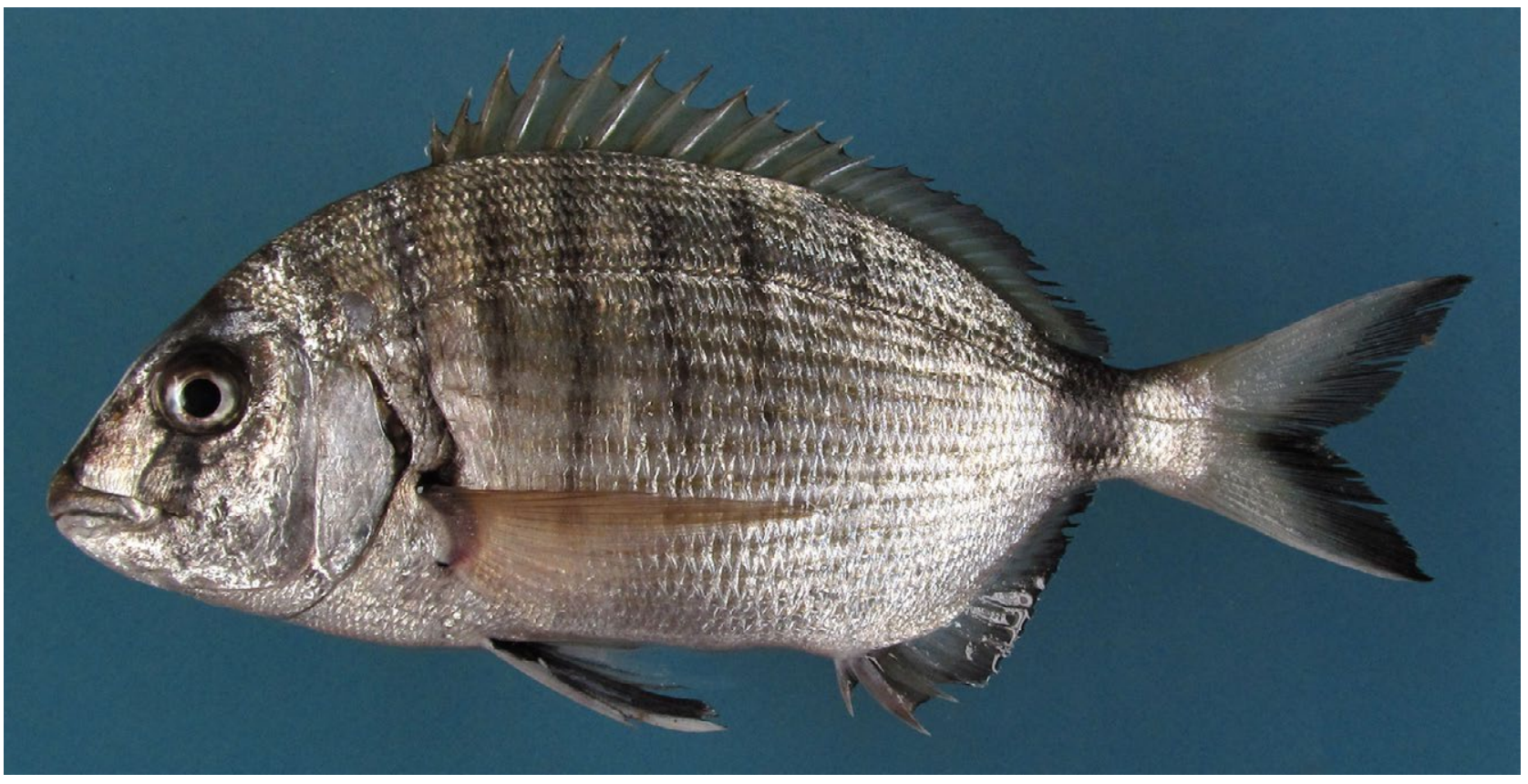

Fig. 1. - Diplodus levantinus n. sp., HUJ 20535, holotype, $184.1 \mathrm{~mm} \mathrm{SL}$, off Jaffa, Israel, 30 Oct. 2015. Lateral view; photograph of the fresh colouration taken a few hours after collection (Photograph: D. Golani). 
Table 1. - Selected body proportions of the holotype and selected paratypes of Diplodus levantinus n. sp., expressed in percentage of standard length.

\begin{tabular}{|c|c|c|}
\hline & Holotype (HUJ 20535, $184.1 \mathrm{~mm} \mathrm{SL)}$ & $\begin{array}{c}\text { Paratypes }(\mathrm{n}=27 \text {; HUJ } 2134,6399,6402,6403, \\
7462,14441,19859,20257,20344, \mathrm{MSNG} \\
58305,50-176 \mathrm{~mm} \mathrm{SL})\end{array}$ \\
\hline Body depth & 44 & $45-50$ \\
\hline Head length & 32 & $32-37$ \\
\hline Horizontal eye diameter & 8 & $8-13$ \\
\hline Tip of snout to dorsal fin origin & 44 & $44-48$ \\
\hline Tip of snout to anal fin origin & 69 & $67-73$ \\
\hline Tip of snout to dorsal fin insertion & 73 & $69-78$ \\
\hline Tip of snout to anal fin insertion & 73 & $70-79$ \\
\hline Tip of snout to pectoral fin origin & 33 & $32-38$ \\
\hline Tip of snout to pelvic fin origin & 39 & $39-45$ \\
\hline Dorsal fin origin to caudal fin base & 72 & $65-72$ \\
\hline Anal fin origin to caudal fin base & 39 & $38-43$ \\
\hline Pectoral fin origin to caudal fin base & 68 & $64-70$ \\
\hline Length of dorsal fin base & 57 & $52-56$ \\
\hline Length of anal fin base & 24 & $22-26$ \\
\hline Length of pectoral fin base & 7 & $7-8$ \\
\hline Length of pectoral fin & 33 & 34-39 \\
\hline Length of pelvic fin & 23 & $23-25$ \\
\hline Length of pelvic fin spine & 15 & $13-16$ \\
\hline Dorsal fin insertion to caudal fin base & 40 & $30-40$ \\
\hline Anal fin insertion to caudal fin base & 35 & $31-35$ \\
\hline Least depth of caudal peduncle & 11 & $9-12$ \\
\hline
\end{tabular}

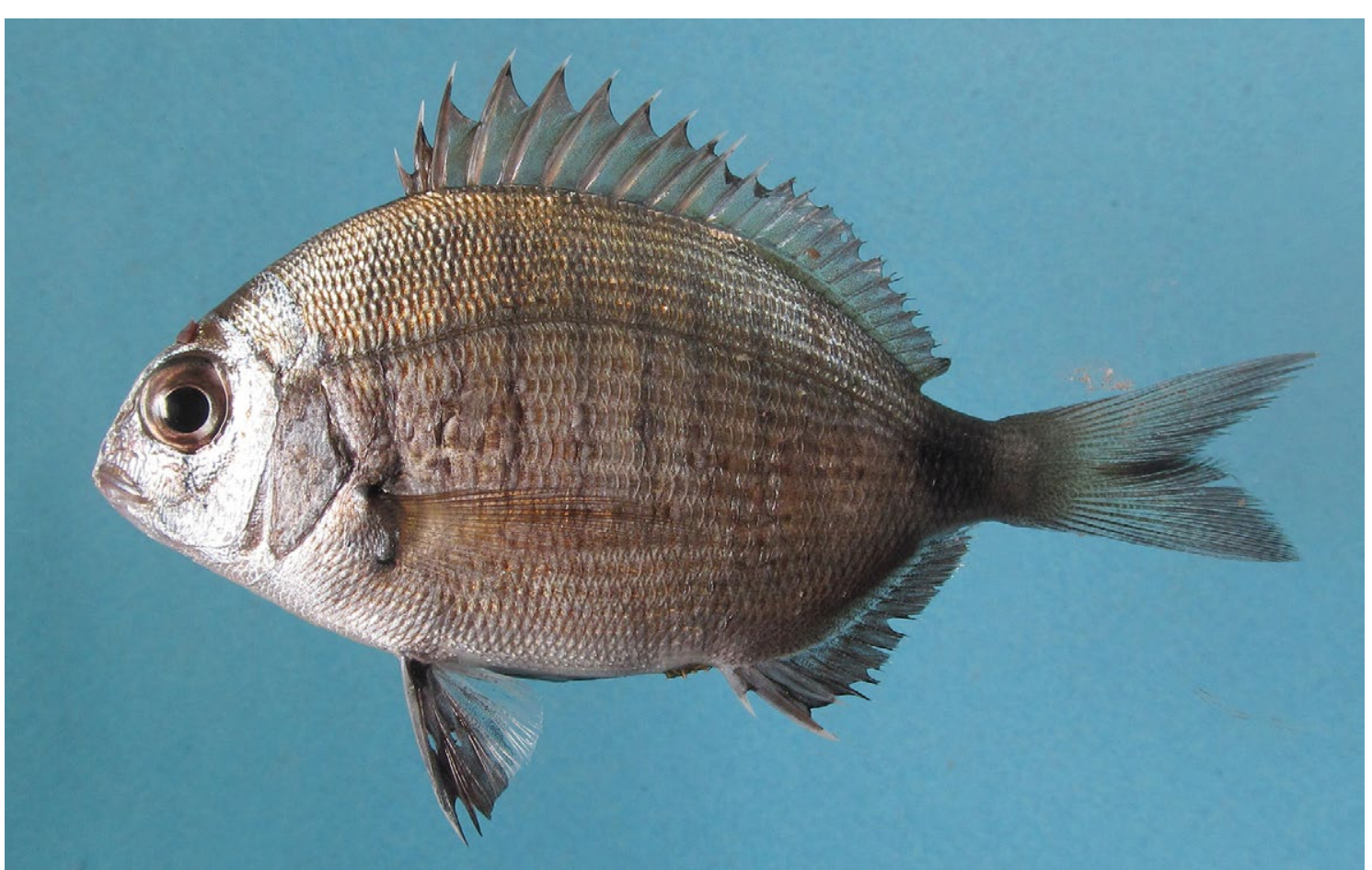

Fig. 2. - Diplodus levantinus n. sp., HUJ 20257, paratype, specimen 1, 95 mm SL, Sdor Yam, Israel, 21 Jan. 2014. Lateral view; photograph of the fresh colouration taken a few hours after collection (Photograph: D. Golani).

Holotype: HUJ 20535, $184.1 \mathrm{~mm}$ SL, eastern Mediterranean Sea, Israel, off Jaffa, ca. $32^{\circ} 03^{\prime} \mathrm{N} 34^{\circ} 45^{\prime} \mathrm{E}$, collected by local fishermen, 30 Oct. 2015

Paratypes: Eastern Mediterranean Sea, Israel: HUJ 2134 (1, 176 mm SL), near mouth of Wadi Hadera, Heinz Steinitz, 24 Oct. 1955 HUJ 6399 (7, 50-72 mm SL), Caesarea, Adam Ben-Tuvia, 25 Sept. 1951. HUJ 6402 (2, 50-76 mm SL), Tanturra, Adam Ben-Tuvia, 4 Apr. 1955. HUJ 6403 (2, 70-76 mm SL), Netanya, Adam Ben-Tuvia, 12 Dec. 1951. HUJ 7462 (1, $231 \mathrm{~mm} \mathrm{SL})$, Caesarea, Asher Ziv, 12 Aug. 1959. HUJ 14441 (1, $139.4 \mathrm{~mm}$ SL), Haifa, Daniel Golani, 5 June 1990. HUJ 19859 (3, 100-114 mm SL), Haifa, Daniel Golani, 28 July 2009. HUJ 20257 (8, 54-95 mm SL), Sdot Yam, 0.5-2.0 m depth, Daniel Golani, 21 Jan. 2014. HUJ 20282 (2, 22-30 mm SL), Jaffa, Daniel Golani, 11 Sept. 2013. HUJ 20344 (1, $128 \mathrm{~mm}$ SL), near mouth of Wadi Hadera, Israel, Heinz Steinitz, 24 Oct. 1955. MSNG 58305 (1, 107 mm SL), Haifa, Daniel Golani, 28 July 2009.
Diagnosis. A species of Diplodus Rafinesque 1810 with 11-12 spines and 10-16 soft rays in the dorsal fin, 3 spines and 11-13 soft rays in the anal fin, 15-17 pectoral fin rays, 6-9 + 8-12 gill rakers on the first gill arch, upper and lower jaws with a single row of 4 incisors on each side, followed by a total of 16-19 molariform teeth in the upper jaw and 12-14 molariform teeth in the lower jaw, with the molariforms of the upper jaw separated from the incisors by a wide gap, and the sides of the body in adults with 8 vertical bars of equal width, which are present even in large adults, followed by a broad bar on caudal peduncle, which usually nearly reaches the ventral margin of the caudal peduncle. 


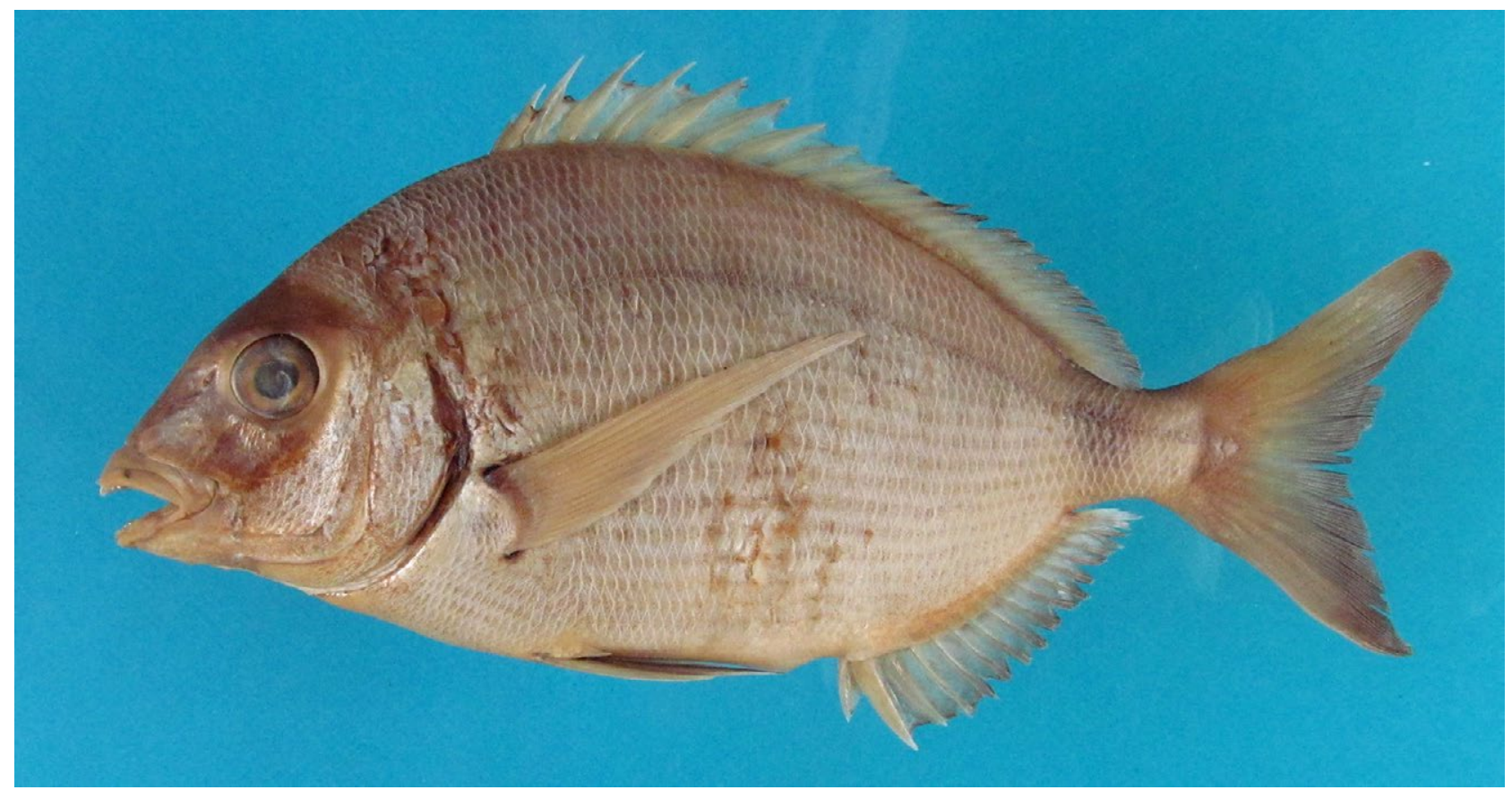

Fig. 3. - Diplodus levantinus n. sp., HUJ 2134, paratype, $176.3 \mathrm{~mm} \mathrm{SL}$, near mouth of Wadi Hadera, Israel, 24 Oct. 1955. Lateral view; photograph of the colouration in preservative taken 60 years after preservation (Photograph: D. Golani).

Description. Dorsal fin-ray formula XII, 13 (XI to XII, 10 to 16 , usually XII, 13 to 14 ). Anal fin ray formula III, 13 (III, 11 to 13). Pectoral fin ray formula, all elements, $16-16$ (15 to 17$)$. Gill rakers $6+9(6-9+8-12)$ on first gill arch.

Selected body proportions, included in Table 1, are part of the description.

Body completely scaled; scales ctenoid. Predorsal scales extending to a point above about centre of eye. Cheeks scaled. Snout scaleless. A long ventral axillary scale. Inter-ray membranes of dorsal, anal, pelvic and pectoral fins scaleless. Small scales extending about three-fourths the way out from base of caudal fin. Lateral line a smooth shallow convex curve from its origin to just beyond end of dorsal fin, then nearly straight to fold formed when tail is bent upward. Four scales (two to four) in a line angling upward, extending onto basal portion of caudal fin. Lateral line scales 68 (59-72). Eight (eight or nine) scales above lateral line to origin of dorsal fin, 16 (16-17) below to origin of anal fin, and seven (seven) above highest curve of lateral line to base of dorsal fin. Maximum observed standard length $231 \mathrm{~mm}$.

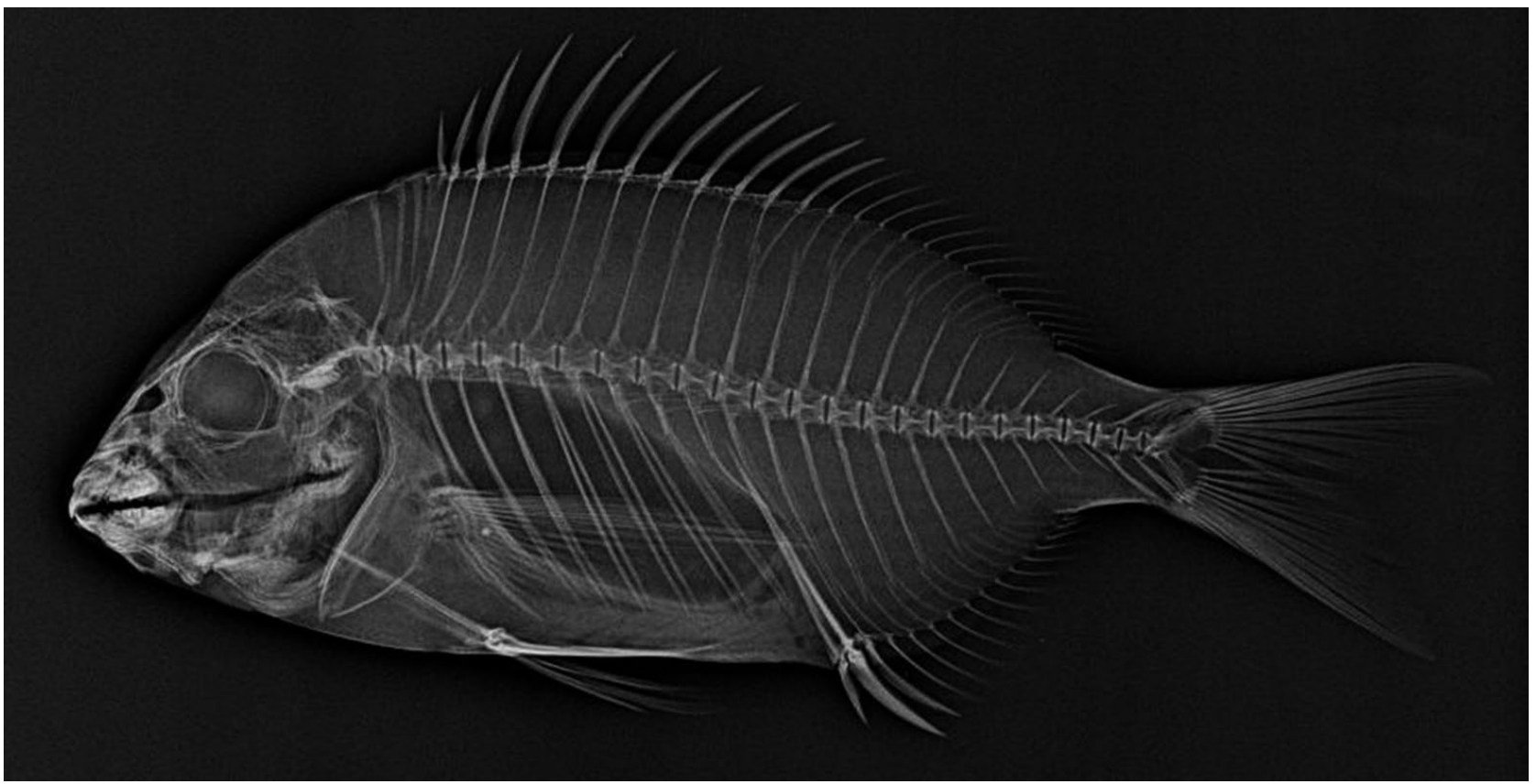

Fig. 4. - Diplodus levantinus n. sp., HUJ 20535, holotype, 184.1 mm SL, off Jaffa, Israel, 30 Oct. 2015. Lateral view; x-ray (Photograph: I. Aizenberg) 
Dorsal outline a regular curve from tip of snout to end (insertion) of dorsal fin, with only a slight concavity above eye and a slight convexity in front of eye. Snout slightly pointed. Ventral outline slightly convex (nearly straight) from tip of snout to pelvic fin origin, thence nearly straight to anal fin origin, and after angling upward at an angle of about $40^{\circ}$, convex to end (insertion) of anal fin. Dorsal and anal fins low. Pectoral fin long, reaching nearly to or past origin of anal fin, and increasing in relative length with increase in body length. Caudal fin forked. Mouth small, maxillary not reaching anterior margin of orbit in small specimens. Anterior nostril round; posterior nostril an elongate oval, the opening slit-like.

A single outer row of incisor teeth, four on each side both upper and lower, and none notched; upper portion of each tooth essentially rectangular in outline above a narrowed base bearing a posterior buttress on inner surface; teeth protrude and are rather strongly incurved towards cutting edge; anterior corner of each lateral tooth elevated. A mosaic of small molariform teeth in posterior part of mouth, 16 (16-19) in upper jaw, 12 (12-14) in lower jaw; anterior part immediately behind incisor teeth is naked; behind these, in lateral posterior part of mouth, there are three (two or three) rows of molariform teeth above, and three (two or three) rows below.

Vertebrae (Fig. 4): 10 precaudal plus 13 caudal plus one hypural, equalling 10 plus 14 as usually recorded. Three predorsal bones. Two dorsal spines situated on first pterygiophore, thereafter one spine on each pterygiophore (a count of 0-0-0-2 as discussed by Smith and Bailey, 1961).

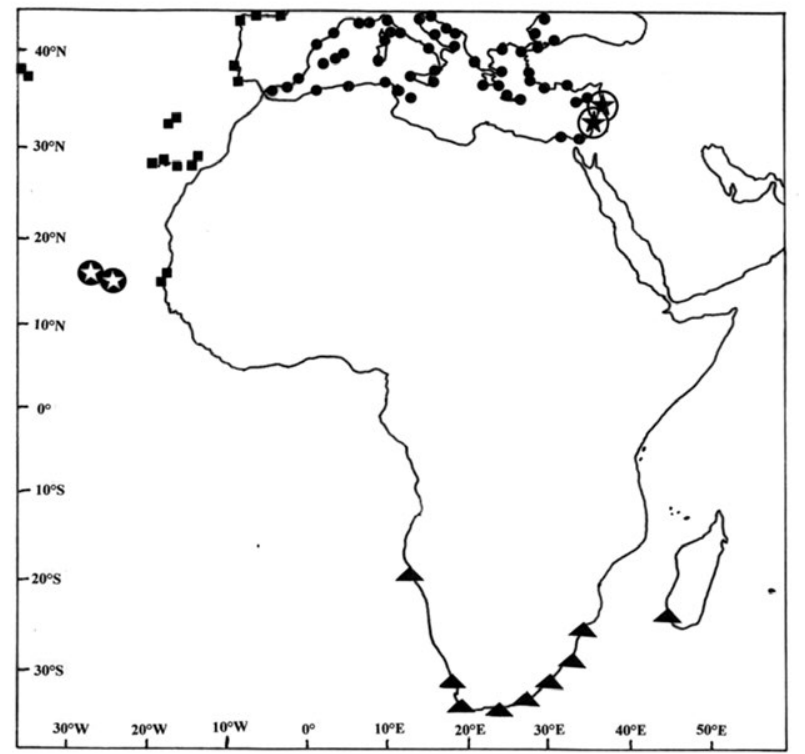

Fig. 5. - Geographical distribution of the species of the Diplodus sargus group in the eastern Atlantic, Mediterranean Sea and southwestern Indian Ocean. Circles, Diplodus sargus; triangles, D. capensis; squares, $D$. cadenati; black stars, $D$. levantinus $\mathrm{n}$. sp.; white stars, D. lineatus.

Colour in alcohol. For pigmentation of body refer to Figures 1-2, which are part of the description.

Head and body silver, scales with horizontal rows of dark pigment. Head dorsally dark grey between the eyes, and a vertical dark streak below the eye. Posterior edge of opercle dark. A dark pectoral axillary blotch. Caudal peduncle with a broad dark grey streak that often reaches to the lower midline. Sides of body with

Table 2. - Comparison of eastern Atlantic and Mediterranean species of the Diplodus sargus species group.

\begin{tabular}{|c|c|c|c|c|c|}
\hline & D. levantinus n. sp. & D. sargus & D. cadenati & D. lineatus & D. capensis \\
\hline Dorsal fin rays & XI-XII, 10-16 & XI-XIII, 12-15 & XI-XIII, 12-15 & XI-XIII, 12-15 & XI-XIII, 13-16 \\
\hline Anal fin rays & III, $11-13$ & III, $12-14$ & III, $12-14$ & III, $12-14$ & III, 13-14 \\
\hline Pectoral fin rays & $15-17$ & $15-17$ & $16-17$ & $15-18$ & $15-17$ \\
\hline ateral line scales & $59-72$ & $57-68$ & $58-67$ & $57-66$ & $61-69$ \\
\hline $\begin{array}{l}\text { Number of molariform } \\
\text { teeth in upper jaw }\end{array}$ & $16-19$ & 28-32 & $39-43$ & 8-10 & $36-41$ \\
\hline $\begin{array}{l}\text { Rows of molariform teeth } \\
\text { in upper jaw }\end{array}$ & $2-3$ & 4 & $4-5$ & $1-2$ & $4-5$ \\
\hline $\begin{array}{l}\text { Number of molariform } \\
\text { teeth in lower jaw }\end{array}$ & $12-14$ & $20-28$ & 27-31 & $3-4$ & $19-22$ \\
\hline $\begin{array}{l}\text { Rows of molariform teeth } \\
\text { in lower jaw }\end{array}$ & $2-3$ & $4-5$ & $4-6$ & 2 & $3-4$ \\
\hline $\begin{array}{l}\text { Extent of molariforms } \\
\text { towards incisors in upper } \\
\text { jaw }\end{array}$ & $\begin{array}{c}\text { Not reaching to base } \\
\text { of incisors, leaving a } \\
\text { wide gap }\end{array}$ & $\begin{array}{l}\text { Nearly reaching to } \\
\text { base of incisors }\end{array}$ & $\begin{array}{l}\text { Reaching to base of } \\
\text { incisors }\end{array}$ & $\begin{array}{c}\text { Not reaching to base } \\
\text { of incisors, leaving a } \\
\text { wide gap }\end{array}$ & $\begin{array}{l}\text { Reaching to base of } \\
\text { incisors }\end{array}$ \\
\hline $\begin{array}{l}\text { Extent of molariforms } \\
\text { towards incisors in lower } \\
\text { jaw }\end{array}$ & $\begin{array}{c}\text { Not reaching to base } \\
\text { of incisors, leaving a } \\
\text { narrow gap }\end{array}$ & $\begin{array}{l}\text { Nearly reaching to } \\
\text { base of incisors }\end{array}$ & $\begin{array}{l}\text { Reaching to base of } \\
\text { incisors }\end{array}$ & $\begin{array}{l}\text { Not reaching to base } \\
\text { of incisors, leaving a } \\
\text { wide gap }\end{array}$ & $\begin{array}{l}\text { Reaching to base of } \\
\text { incisors }\end{array}$ \\
\hline $\begin{array}{l}\text { Large adults: vertical bars } \\
\text { on body }\end{array}$ & 8 of equal width & None & $\begin{array}{l}\text { Alternatingly } 5 \text { wide, } \\
3-4 \text { narrow, total } 8-9\end{array}$ & $\begin{array}{l}4 \text { of equal width, } 1 \\
\text { narrow }\end{array}$ & None \\
\hline $\begin{array}{l}\text { Medium-sized adults: } \\
\text { vertical bars on body }\end{array}$ & 8 of equal width & $\begin{array}{l}\text { Alternatingly } 4-5 \\
\text { wide, } 3-4 \text { narrow, } \\
\text { total 8-10 }\end{array}$ & $\begin{array}{l}\text { Alternatingly } 4-5 \\
\text { wide, } 3-4 \text { narrow, } \\
\text { total } 7-9\end{array}$ & $\begin{array}{c}4 \text { of equal width, } 1 \\
\text { narrow }\end{array}$ & 9 of equal width \\
\hline $\begin{array}{l}\text { Small adults: vertical bars } \\
\text { on body }\end{array}$ & 8 of equal width & $\begin{array}{l}\text { Alternatingly } 4-5 \\
\text { wide, } 3-4 \text { narrow, } \\
\text { total } 9-10\end{array}$ & 5 of equal width & 4-5 of equal width & 9 of equal width \\
\hline $\begin{array}{l}\text { Extent of dark blotch on } \\
\text { caudal peduncle }\end{array}$ & $\begin{array}{l}\text { Nearly reaching } \\
\text { ventral margin }\end{array}$ & $\begin{array}{l}\text { Usually only on upper } \\
\text { three-fourths }\end{array}$ & $\begin{array}{l}\text { Only on upper } \\
\text { three-fourths }\end{array}$ & $\begin{array}{l}\text { Only on upper half } \\
\text { to upper three- } \\
\text { fourths }\end{array}$ & $\begin{array}{l}\text { Only on upper } \\
\text { three-fourths }\end{array}$ \\
\hline
\end{tabular}




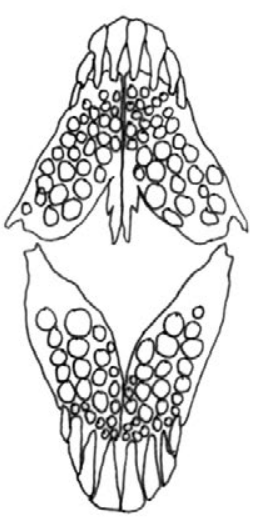

A

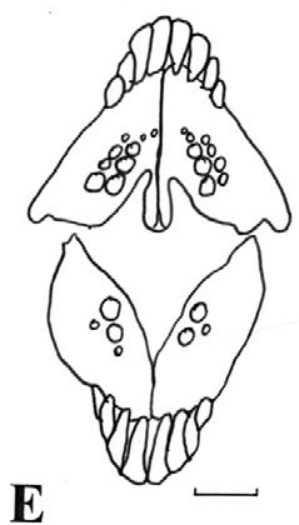

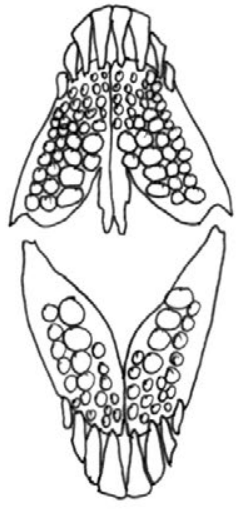

B

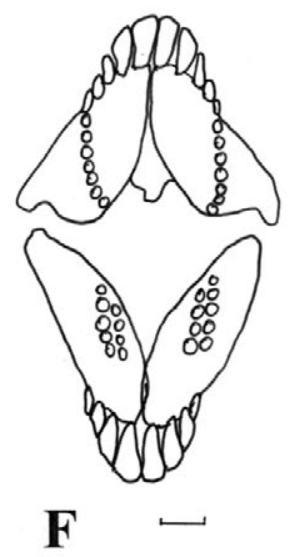

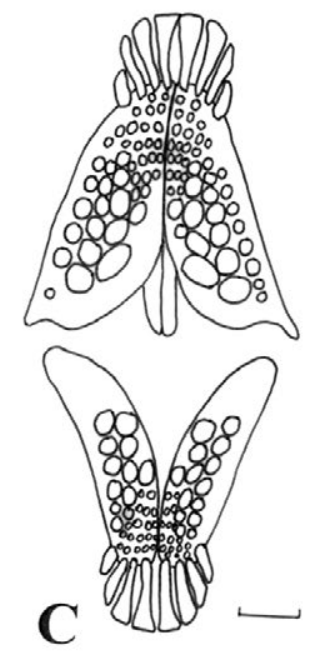

D
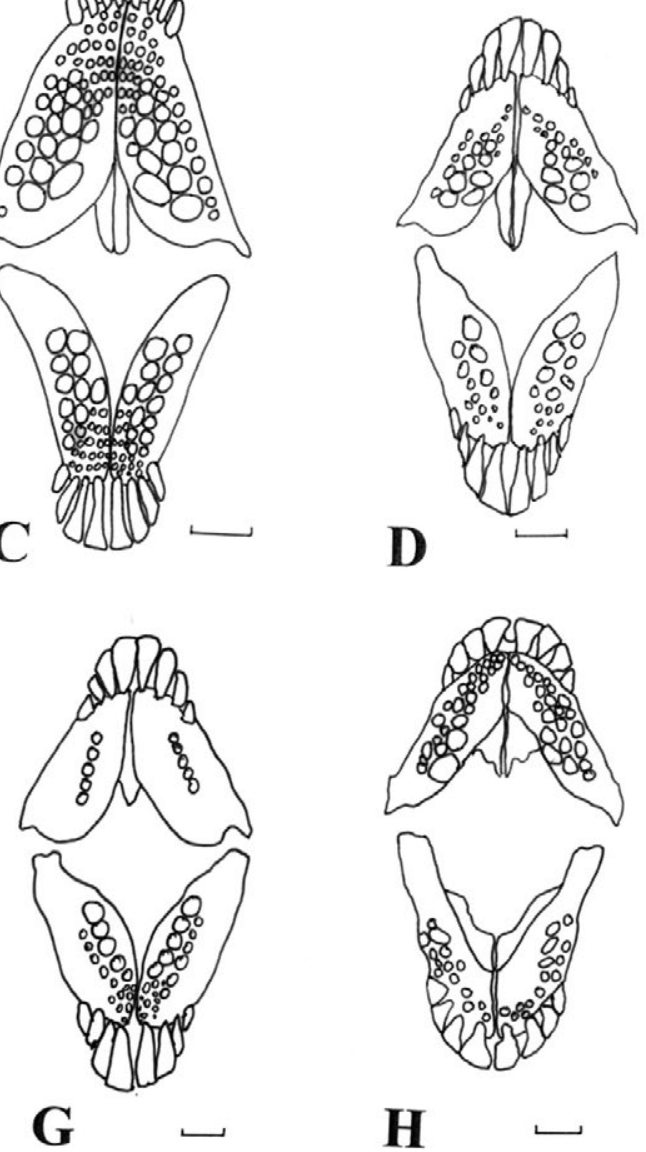
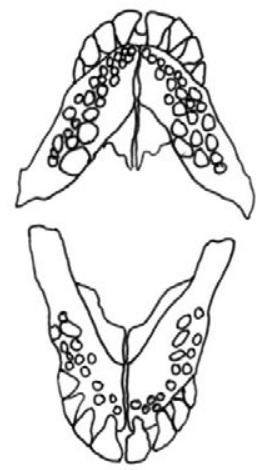

$\mathbf{H}$

Fig. 6. - Dentition of the species of the eastern Atlantic and Mediterranean species of the Diplodus sargus group and similar species; (above) upper jaw, (below) lower jaw. A, Diplodus sargus, SMNS 9153, specimen 1, $190 \mathrm{~mm}$ SL, Croatia, Istria, 9 June 1978. B, Diplodus capensis, SMNS 25672, 1 specimen, 176 mm SL, South Africa. C. Diplodus cadenati, HUJ 20534, specimen 1, 198 mm SL, Senegal, Dakar, Apr. 2015. D, Diplodus levantinus n. sp., HUJ 7462, 1 paratype, $231 \mathrm{~mm}$ SL, Israel, Caesarea, 12 Aug. 1959. E, Diplodus lineatus, HUJ 20368, specimen 1, 222 mm SL, Cape Verde Islands, Boa Vista Island, 9 Sept. 2014. F, Diplodus fasciatus, HUJ 20369, specimen 1, 199 mm SL, Cape Verde Islands, Boa Vista Island, 9 Sept. 2014. G, Diplodus prayensis, HUJ 20370, 199 mm SL, Cape Verde Islands, Boa Vista Island, 9 Sept. 2014. H, Diplodus annularis, SMNS 995, specimen 3, $181 \mathrm{~mm} \mathrm{SL}$, Italy, Trieste, Dec. 1862. Scales indicate $3 \mathrm{~mm}$.

about eight narrow vertical bars that extend across the upper three-fourths of the body; the posterior two bars are present but not very well visible on the photograph of the holotype due to light reflections (Fig. 1). Pectoral fins immaculate. Inter-spine and inter-ray membranes of dorsal, anal and caudal fins tinged with dark pigment, which is more intense towards bases of fins. Anterior inter-ray membranes of pelvic fins dark, more so than those of dorsal, anal and caudal fins; the spine and the first membrane are white, however, as are the posterior membranes. Caudal fin distally dark grey.

Etymology. The name of the new species, levantinus, refers to the Levant, a historical name for the coasts of the eastern Mediterranean.

Distribution and habitat. Known only from the coast of Israel, eastern Mediterranean Sea, between Haifa and Jaffa (Fig. 5). The species is found from shallow water to $50 \mathrm{~m}$ depth, usually on sand bottom near rocks; juveniles are found above sandy substrate near rocks at depths of $0.2-2 \mathrm{~m}$.
Comparisons. The dentition and colouration of the eastern Atlantic and Mediterranean species are compared in Figs 6-7 and Table 2. The new species is distinguished from $D$. sargus (Mediterranean Sea except Israel; Figs 8, 6A, 7A-C) by the number of molariform teeth in the upper and lower jaws in juveniles and adults (D. sargus: upper jaw 28-32, 4 rows; lower jaw 20-28, 4-5 rows. D. levantinus n. sp.: upper jaw 16-19, 2-3 rows; lower jaw: 12-14, 2-3 rows), the molariform teeth which do not extend to the base of the incisors in the upper jaw but leave a wide gap (nearly extending to the base of the incisors in D. sargus), the presence of vertical bars on the sides of the body in large specimens (usually absent in D. sargus), and sides of body in moderate and small adults with bars of equal width (usually alternating wide and narrow bars in $D$. sargus). It differs from $D$. cadenati (eastern Atlantic; Figs $9,6 \mathrm{C}, 7 \mathrm{G}-\mathrm{I}$ ) in the number of molariform teeth in the upper and lower jaws in juveniles and adults (D. cadenati: upper jaw 39-43, 4-5 rows; lower jaw: 27-31, 4-6 rows. D. levantinus n. sp.: upper jaw 16-19, 2-3 rows; lower jaw: 12-14, 2-3 rows), the molariform teeth 

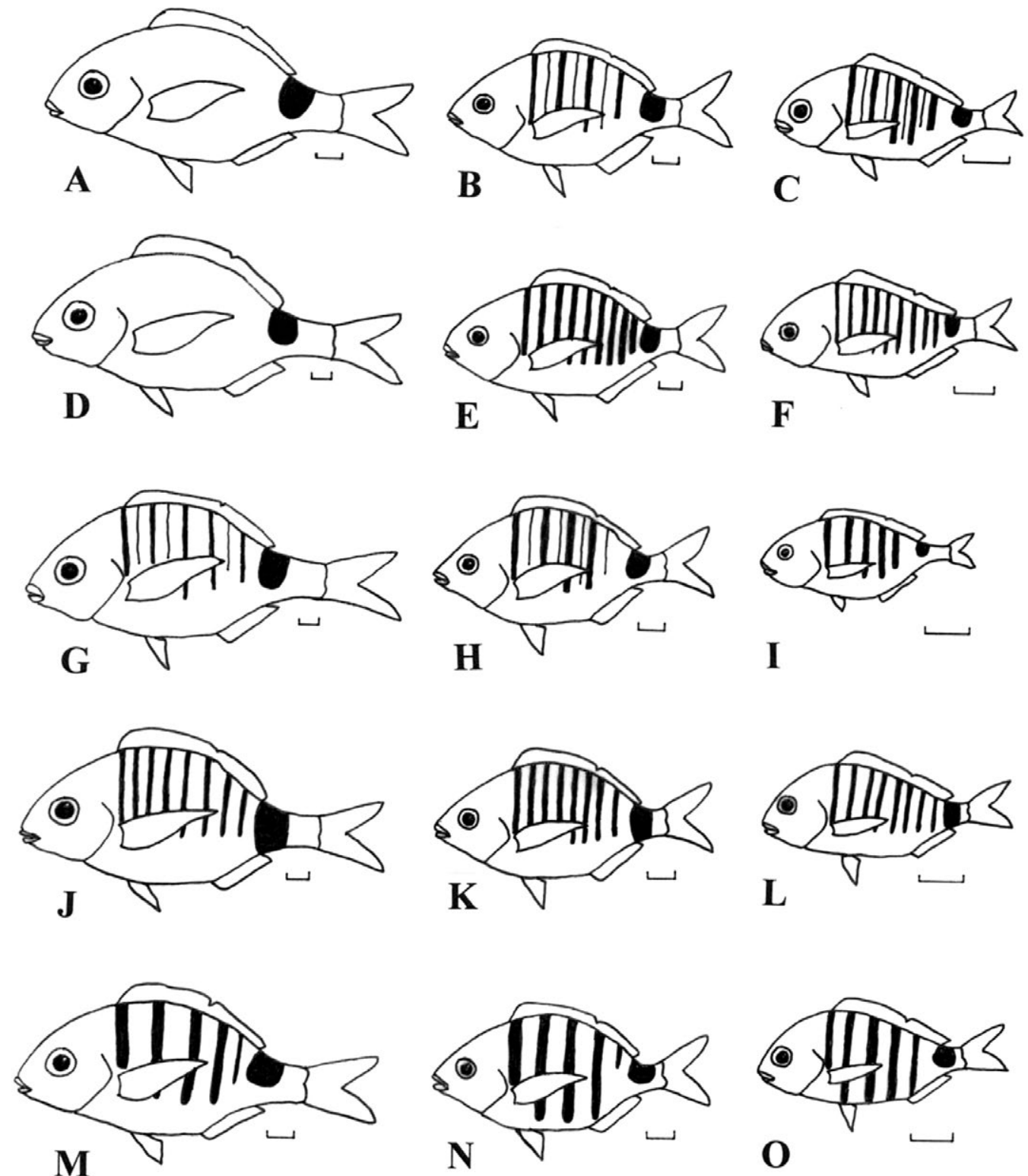

Fig. 7. - Generalised body colour patterns of the species of the Diplodus sargus group; large adults, medium adults and small adults. Diplodus sargus: A, MNHN A-8098 (255 mm SL), France, Marseille; B, MNHN 1961-0894 (192 mm SL), Monaco, 1961. C, MNHN uncat. (92 mm SL), France, Villefranche-sur-Mer. Diplodus capensis: D, MNHN A-8096 (315 mm SL), South Africa, Cape Province. E, MRAC 97894 (215 mm SL), South Africa, Elephant Bay. F, SAIAB 1638 (109 mm SL), South Africa, Cape Province. Diplodus cadenati: G, BMNH 1895.5.28.24 (310 mm SL), Madeira. H, BMNH 1858.8.3.7-8 (182 mm SL), Canary Islands. I, IFAN 867 (89 mm SL), Senegal, Dakar. Diplodus levantinus n. sp.: J, HUJ 7462 (281 mm SL, paratype), Israel, Caesarea, 12 Aug. 1959. K, HUJ 2134 (176.3 mm SL, paratype), Israel, Wadi Hadera, 24 Oct. 1955. L, HUJ 20257 (spec. 1, 95 mm SL, paratype), Israel, Sdot Yam, 21 Jan. 2014. Diplodus lineatus: M, HUJ 20368 (spec. 1, 222 mm SL), Cape Verde Islands, Boa Vista, 9 Sept. 2014. N, HUJ 20369 (spec. 2, 177 mm SL), Cape Verde Islands, Boa Vista, 9 Sept. 2014. O, MNHN 1971-0002 (98 mm SL), Cape Verde Islands. This figure follows Paz (1975: 47), but is corrected and updated; figures A-I and O based on Paz (1975: Fig. 23). Scales indicate $20 \mathrm{~mm}$.

which do not extend to the base of the incisors in the upper jaw but leave a wide gap (extending to the base of the incisors in $D$. cadenati), sides of body in large and moderate adults with bars of equal width (usually alternating wide and narrow bars in $D$. cadenati), sides of body in small adults with 8 vertical bars (with about 5 vertical bars in $D$. cadenati), and the black blotch on the caudal peduncle usually nearly reaching the ventral margin (usually only covering the upper three-fourths in $D$. cadenati). It is distinguished from $D$. lineatus (Cape Verde Islands; Figs 10, 6E, 7M-O) by the number of molariform teeth in the upper and lower jaws in juveniles and adults (D. lineatus: upper jaw 8-10, 1-2 rows; lower jaw: 3-4, 2 rows. D. levantinus n. sp.: upper jaw 16-19, 2-3 rows; lower jaw: 12-14, 2-3 rows), sides of body in small adults with 8 vertical bars (with 4-5 vertical bars in $D$. lineatus), and the black blotch on the caudal peduncle usually nearly reaching the ventral margin (usually only covering the upper half to upper three-fourths in $D$. lineatus). It differs from $D$. capensis (South Africa; Figs 6B, 7D-F) in the number of molariform teeth in the upper and lower jaws in juveniles and adults (D. capensis: upper jaw 36-41, 4-5 rows; lower jaw: 19-22, 3-4 rows. D. levantinus n. sp.: up- 

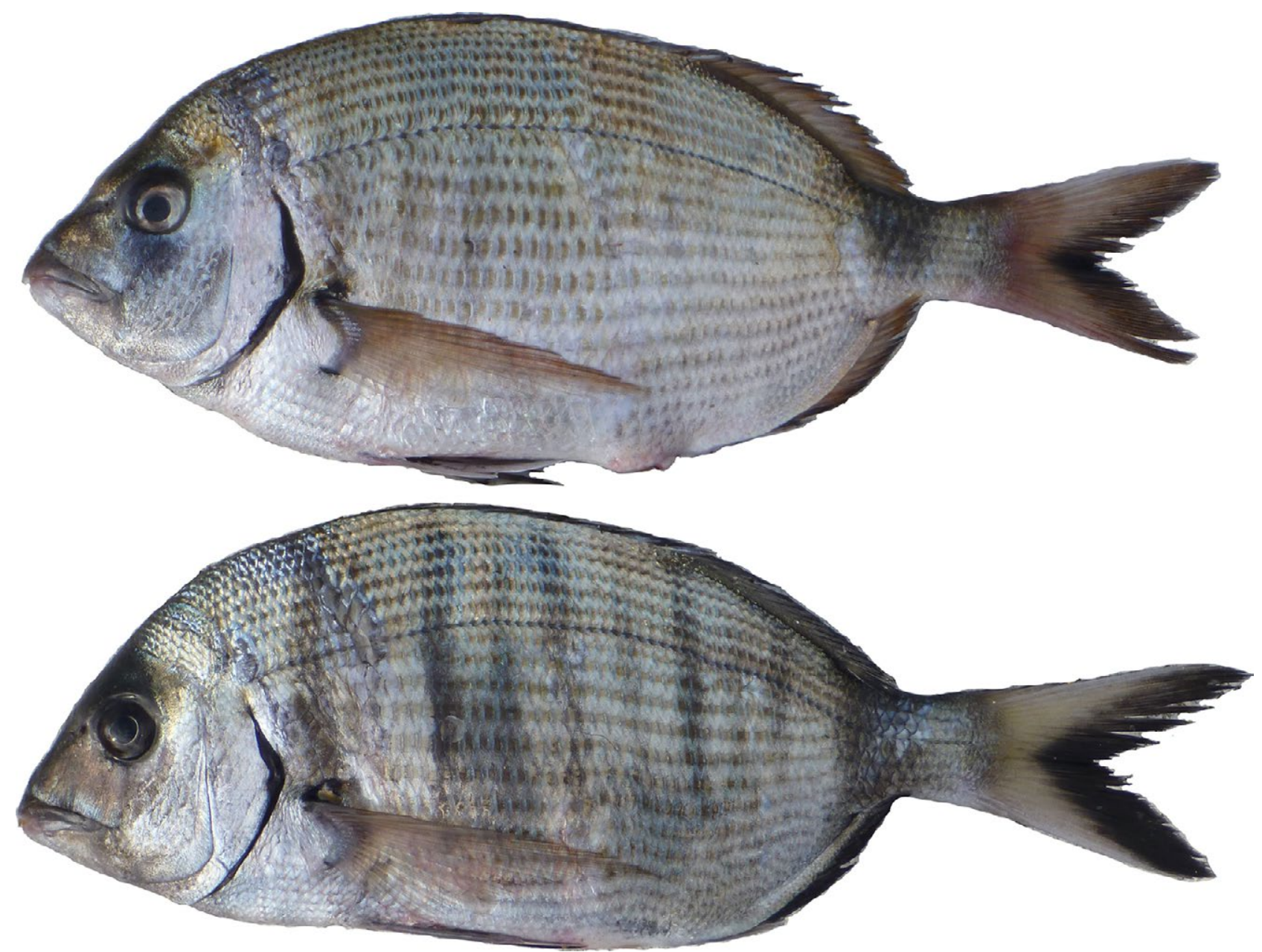

Fig. 8. - Diplodus sargus, HUJ 20542, 2 spec., 220-225 mm SL, France, Marseille, 8 Dec. 2015. Lateral view; photograph of the fresh colouration taken a few hours after collection (Photograph: R. Fricke).

per jaw 16-19, 2-3 rows; lower jaw: 12-14, 2-3 rows), the molariform teeth, which do not extend to the base of the incisors in the upper jaw but leave a wide gap (extending to the base of the incisors in D. capensis), the presence of vertical bars on the sides of the body in large specimens (absent in D. capensis), and sides of body in moderate and small adults with 8 vertical bars (with 9 vertical bars in $D$. capensis). The new species is distinguished from $D$. argenteus (western Atlantic), D. ascensionis (Ascension Island), D. bermudensis (western Atlantic), D. caudimacula (western Atlantic), D. helenae (St. Helena), D. holbrookii (western Atlantic), D. kotschyi (northwestern Indian Ocean) and D. noct (Red Sea) by the presence of vertical bars on the sides of the body in large specimens (absent in $D$. argenteus, D. ascensionis, D. bermudensis, D. caudimacula, D. helenae, D. holbrookii, D. kotschyi and D. noct), sides of body in moderate and small adults with 8 vertical bars (with 9 vertical bars in $D$. argenteus, $D$. bermudensis, D. caudimacula, D. helenae, D. kotschyi, and $D$. noct), and the black blotch on the caudal peduncle usually nearly reaching the ventral margin (usually only covering the upper three-fourths in D. argenteus,
D. ascensionis, D. bermudensis, D. caudimacula, D. holbrookii, D. noct and D. kotschyi, in large specimens restricted to a round blotch in the middle in $D$. kotschyi and D. noct).

\section{DISCUSSION}

The southeastern Mediterranean (Levantine) populations previously attributed to Diplodus sargus clearly belong to a different species, based on differences in the dentition and colouration. The only junior synonym of D. sargus listed in the Catalogue of Fishes online (Eschmeyer and Fricke 2015) that was described from the eastern Mediterranean, Sargus raucus Geoffroy Saint-Hilaire, 1809, was first considered as the valid name for these; the species was illustrated from Egypt by Geoffroy Saint-Hilaire (1809: pl. 18, Fig. 1), and no type material is available. The material was collected in Alexandria, Egypt in 1798-1799, and when Alexandria was conquered by Britain, Geoffroy Saint-Hilaire refused to hand over the materials and documents to the British general Hutchinson, and later sent the material to Paris (Bauchot et al. 1990: 88). However, Bauchot and 


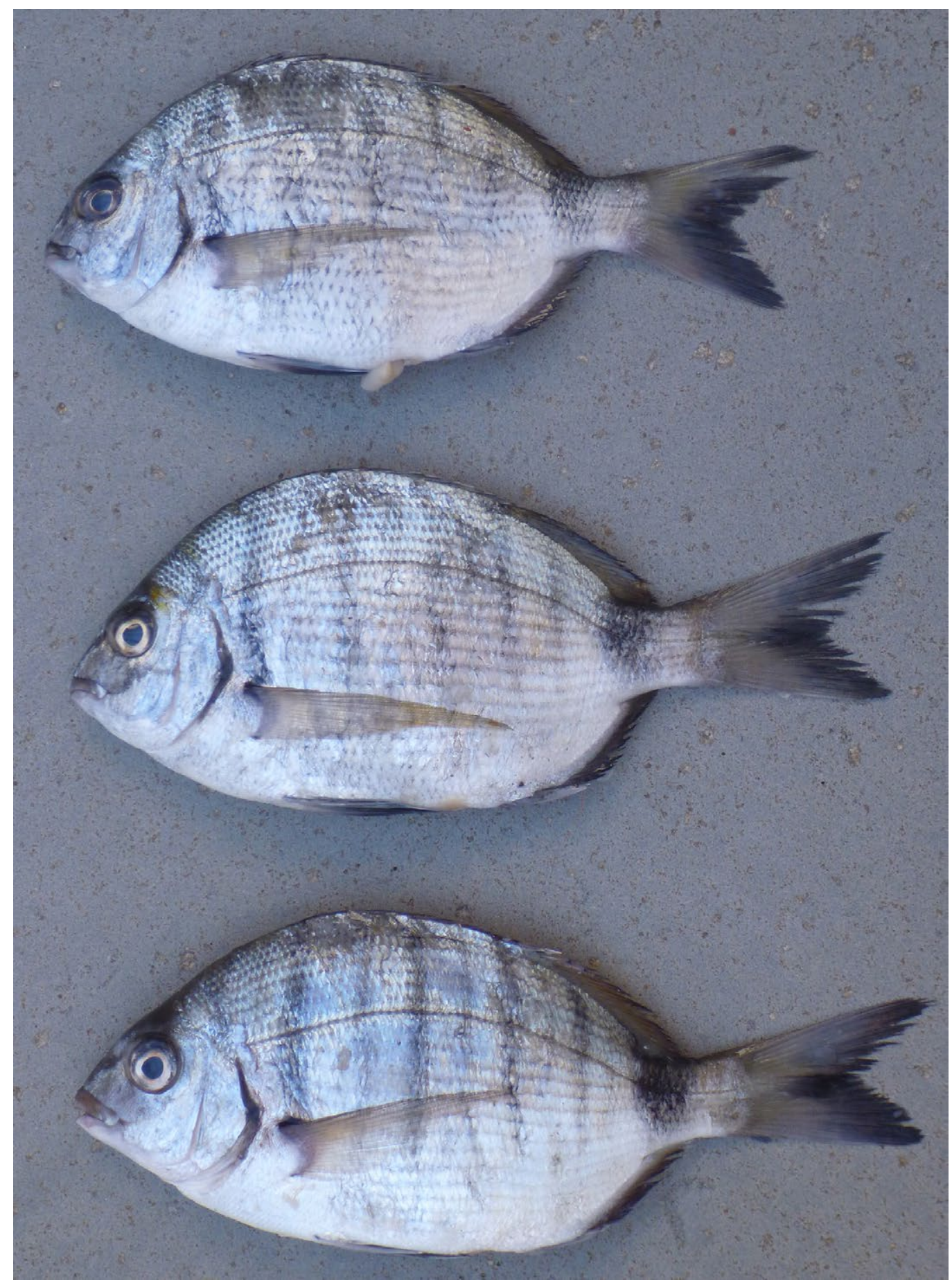

Fig. 9. - Diplodus cadenati, HUJ 20532, 3 spec (upper to lower: 151, 149, $140 \mathrm{~mm}$ SL), Tenerife, Canary Islands, 25 July 2015. Lateral view; photograph of the fresh colouration taken a few hours after collection (Photograph: R. Fricke).

Daget (1971: 322) found two specimens of Sargus raucus from Alexandria (MNHN 0000-5740), which were used for the description of Geoffroy Saint-Hilaire (1827: 340), and identified them as Diplodus cervinus (Lowe 1838). None of the specimens agrees with the holotype illustrated by Geoffroy Saint-Hilaire (1809: Pl. 38, Fig. 1 ), which is a smaller specimen and clearly belongs to the Diplodus sargus species group, so the holotype is not included in MNHN 0000-5740. The material collected by E. Geoffroy Saint-Hilaire in Egypt was exclusively sent to Paris, but no other material of the Diplodus sar- gus species group collected during the Egyptian mission is extant in the MNHN collection (see also Bauchot and Daget 1972: 69). We therefore conclude that the holotype is lost. A specimen from Bardawil Lagoon, Egypt (HUJ 6047), very similar in colouration to the one illustrated by Geoffroy Saint-Hilaire (1809), turned out to have the typical dentition of Diplodus sargus with irregularly grouped small molars reaching right to the front teeth, without a naked area in between. The specimen has a dorsal fin count of XII+13, an anal fin count of III +13 , pectoral fin rays 16 , gill rakers $5+8$. In 


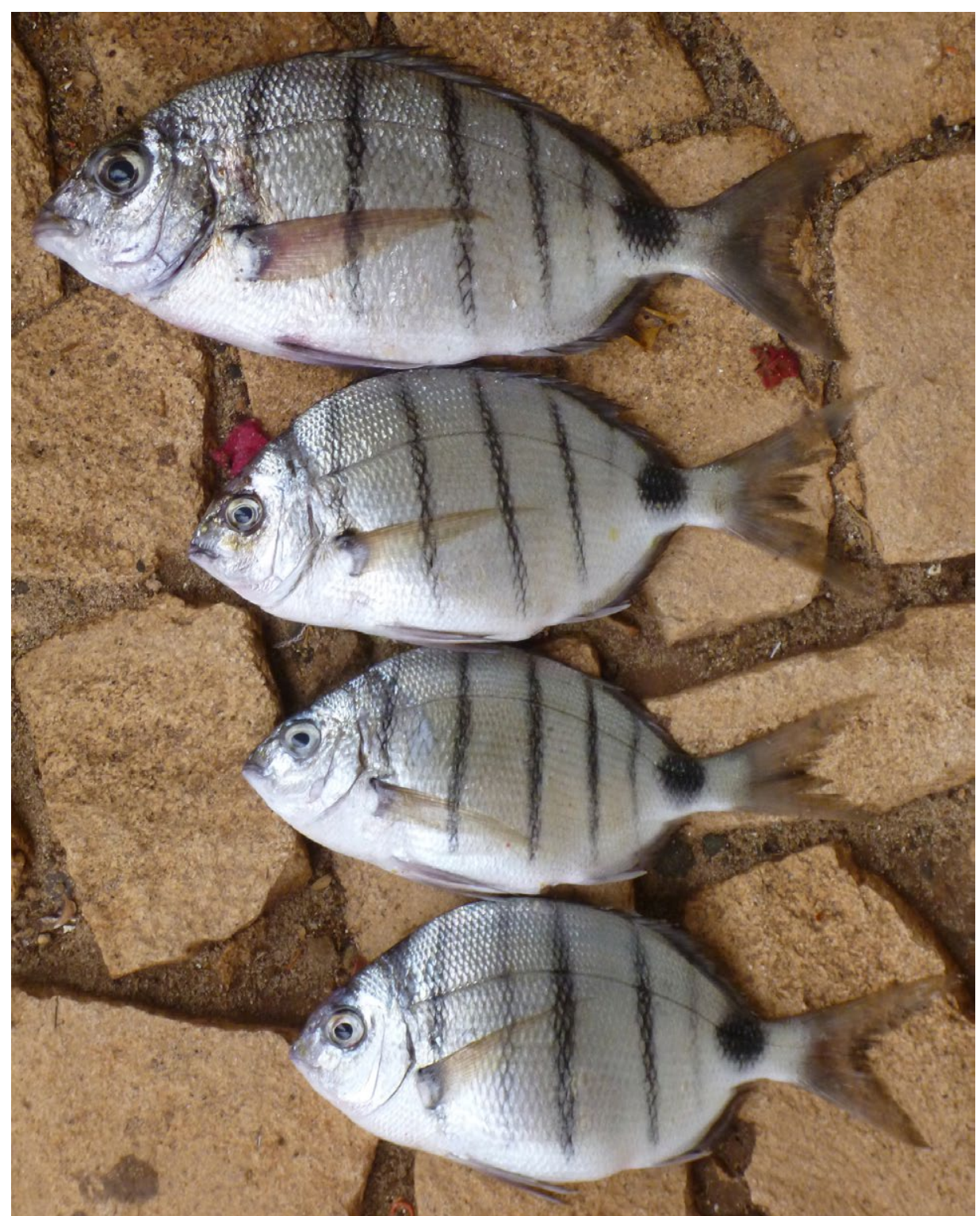

Fig. 10. - Diplodus lineatus, HUJ 20368, 4 spec (Upper to lower: 222, 176, 166, 162 mm SL), Boa Vista, Cape Verde Islands, 9 Sept. 2014. Lateral view; photograph of the fresh colouration taken a few hours after collection (Photograph: R. Fricke).

order to avoid nomenclatural confusion, and to fix the classification of southeastern Mediterranean species in the Diplodus sargus group, the specimen (HUJ 6047) is hereby designated as the neotype of Sargus raucus Geoffroy Saint-Hilaire, 1809 (Fig. 11), which is thus a junior synonym of Diplodus sargus (Linnaeus, 1758). The neotype originates from Bardawil Lagoon, northern Sinai, Egypt, which is as close as possible to the original type locality (Egypt). A second specimen from Bardawil Lagoon (HUJ 6057) also agrees in the dentition and general characters with Diplodus sargus. A third specimen, ZMB 1055 (70.5 mm SL) from Alexandria, Egypt, collected during the expedition of Hemprich and Ehrenberg, has likewise a dentition typical of Diplodus sargus. It can be concluded that Diplodus sargus is found along the Mediterranean coast of Egypt, while the species is replaced by $D$. levantinus $\mathrm{n}$. sp. in Israel.

The difference of the Israeli population from other species of the Diplodus sargus species group were first recognized in the doctoral dissertation of Paz (1975: 57), who provisionally named the specimens from Israel "Diplodus X" and assumed that they were hybrids between $D$. annularis $\times D$. sargus, due to the dentition, which seemed intermediate between those species. However, the hybrid theory can be ruled out, as no true Diplodus sargus is found in Israel, and genetically they are clearly part of the Diplodus sargus species group, without a component of another species of Diplodus (Yaron Tikochinski, personal communication). Except in the work of Paz (1975), the distinctiveness of Israeli populations previously misidentified as $D$. sargus was neither mentioned nor discussed again in the literature, including the later paper of Paz (1982).

The body shape and colouration changes during growth in Diplodus spp.; juveniles are more slender, adults more high-bodied, and in some species the number of stripes along the sides of the body increases. Allometric growth in Diplodus sargus compared with 


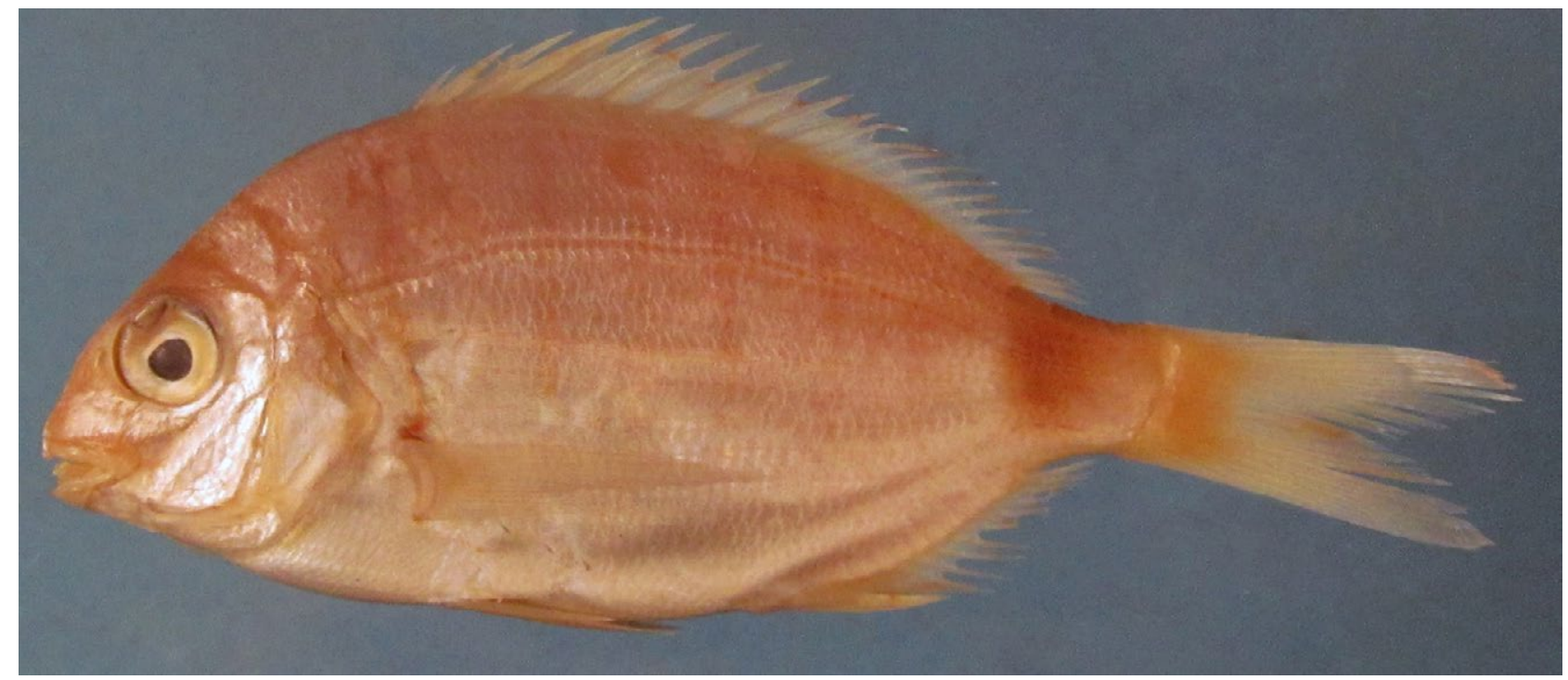

Fig. 11. - Diplodus sargus, HUJ 6047, neotype of Sargus raucus Geoffroy Saint-Hilaire 1809, 64.3 mm SL, Bardawil Lagoon, Egypt (Photograph: D. Golani).

two other species of the genus was analysed by Loy et al. (2001). Allometric growth is also obvious in Diplodus levantinus $\mathrm{n}$. sp., but the number of stripes along the sides of the body does not change from juveniles to adults in this species.

Considering the genetics of species in the Diplodus sargus species group, no genetic differences were found between Diplodus sargus and D. cadenati by Domingues et al. (2007). They agreed with Bargelloni et al. (2005) who considered two hypotheses to explain this lack of differentiation. Either D. sargus is a recent immigrant in the Mediterranean or historical bottlenecks and recolonization processes prevented strong differentiation of Atlantic and Mediterranean basins. In a genetic study of several species of Diplodus, including D. levantinus n. sp., D. sargus and D. lineatus, no significant differences were found among these species (Yaron Tikochinski, personal communication). On the other hand, the Diplodus sargus species group is well distinguished from other species of Diplodus (see Summerer et al. 2001, Casu et al. 2009). However, González-Wangüemert et al. (2006) detected diagnostic alleles differentiating between Diplodus sargus and $D$. cadenati; additional molecular analyses should be performed for the species group. Apart from potential genetical differences, the species in the Diplodus sargus species group are sufficiently distinguished by their dentition and colouration.

The restricted range of Diplodus levantinus n. sp. appears to represent a relict distribution; its particular dentition recalls that of $D$. lineatus from the Cape Verde Islands, which is also considered a relict distribution. Species with a stronger dentition (including D. sargus in the Mediterranean) seem to have spread over most of the range of the species group, leaving the species with weaker dentition in such small, restricted areas at the margin. The range of $D$. levantinus is separated from that of D. sargus by wide stretches of sandy shore without suitable habitat in the south; the situation in the north of its distribution range remains unknown.

\section{CHECKLIST OF SPECIES OF THE GENUS DIPLODUS}

Diplodus annularis (Linnaeus, 1758)

Sparus unicolor flavescens, macula nigra annulari ad caudam Artedi 1738a: 37, No. 12 (based on Artedi $1738 \mathrm{~b}$; Sparus of authors).

Sparus unicolor flavescens, macula nigra annulari ad caudam Artedi 1738b: 57, No. 1 (based on Ruàs of Aristoteles and Aelianus; Sparos of Athenaeus, Oppianus and Eustathius; Sparus of Plinius, Albertinus, Cubae, Bellonius, Rondeletius, Salviani, Aldrovandius, Jonston, Charleton, Willughby, Rajus; Marinus of Gesner; Sparulus of Ovidius; Fluta and Sargus of Gaza; Caspargus of Aelianus).

Sparus annularis Linnaeus, 1758: 278 (in mari Adriatico, infero/Adriatic Sea; no types known; based on 'Art. gen. 37, syn. 57, Sparus unicolor flavescens ...). Sparus sparulus Lacepède, 1802: 26, 76 [part: Mediterranean Sea; syntypes: MNHN A.125 (2)].

Sparus sparlotus Rafinesque, 1810b: 49 (Toscana, Italy; no types known).

Sciaena melanura Pallas, 1814: 254 (Eupatoria/Samsun, Turkey, Black Sea; no types known).

Distribution: Mediterranean Sea, Black Sea and Sea of Azov; eastern Atlantic from Canary Islands north to Bay of Biscay.

Diplodus argenteus (Valenciennes in Cuvier and Valenciennes, 1830)

Sargus argenteus Valenciennes in Cuvier and Valenciennes, 1830: 60 [Brazil; syntypes: MNHN 8555 (3), A-8105 (1)].

Sparus sargo Larrañaga, 1923: 379 (Uruguay; no types known).

Distribution: western Atlantic from Brazil to Argentina.

Diplodus ascensionis (Valenciennes in Cuvier and Valenciennes, 1830)

Sargus ascensionis Valenciennes in Cuvier and Va- 
lenciennes, 1830: 61 [Ascension Island; syntypes: MNHN 8582 (2)].

Distribution: Ascension Island.

Diplodus bellottii (Steindachner, 1882)

Sargus bellottii Steindachner, 1882: 42 (Arglim Bank, Canary Islands; holotype: not found).

Diplodus senegalensis Cadenat, 1964: 968, Figs 6, 7, 25 [Port-Étienne, Mauritania; Senegal; syntypes: IFAN uncat. (15)].

Distribution: southwestern Mediterranean Sea (Malaga to Gibraltar); eastern Atlantic from Cape Verde Islands north to Cadiz (Spain).

Diplodus bermudensis Caldwell, 1965

Diplodus bermudensis Caldwell, 1965: 217, Fig. 1 (Bermuda; holotype: FMNH 75520).

Distribution: Bermuda.

Diplodus cadenati Paz, Bauchot and Daget, 1974

Diplodus sargus typicus Cadenat, 1964: 960 (part: West Africa).

Diplodus cadenati Paz, Bauchot and Daget, 1974: 113, Figs 2, 3 A-B (Puerto de la Cruz, Tenerife, Canary Islands; holotype: MNHN 1971-0029).

Diplodus sargus sargus (non Linnaeus, 1758): Quéro and Guéguen 1978: 85 (Golfe de Gascogne, France, northeastern Atlantic).

Distribution: eastern Atlantic from Senegal north to Madeira, Azores and Bay of Biscay.

Diplodus capensis (Smith, 1844)

Sargus capensis Smith, 1844: unpaginated, pl. 23, Fig. 2 (East Cape, South Africa; holotype: BMHH 1845.7.3.52)

Distribution: Angola, Namibia, South Africa, southern Mozambique, southern Madagascar.

Diplodus caudimacula (Poey, 1860)

Sargus caudimacula Poey, 1860: 198 [Cuba; syntypes: MCZ 21715 (1), USNM 100938 (1, ex 4693)].

Distribution: Caribbean Sea north to southern Florida.

Diplodus cervinus (Lowe, 1838)

Sparus trifasciatus Rafinesque, 1810b: 50, No. 135 (Sicily, Italy; no types known).

Sargus raucus (non Geoffroy Saint-Hilaire, 1809): Geoffroy Saint-Hilaire 1827: 340 [part: Alexandria, Egypt.]

Charax cervinus Lowe, 1838: 177 (Lanzarote, Canary Islands; neotype: BMNH 1859.5.4.4 or 1859.5.4.1, as designated by Bauchot and Daget 1971: 321).

Distribution: Mediterranean Sea; eastern Atlantic from Cape Verde Islands north to Madeira and Bay of Biscay.

Diplodus fasciatus (Valenciennes in Cuvier and Valenciennes, 1830)

Sargus fasciatus Valenciennes in Cuvier and Valenciennes, 1830: 59 [Cape Verde Islands; syntypes: MNHN A.8099 (1), A.8100 (1)].

Distribution: Cape Verde Islands.
Diplodus helenae (Sauvage, 1879)

Sargus helenae Sauvage, 1879: 205 (Saint Helena Island; holotype: MNHN A.0952).

Distribution: Saint Helena Island.

Diplodus holbrookii (Bean, 1878)

Sargus holbrookii Bean, 1878: 198 [Savannah Bank, Charleston, South Carolina, USA; syntypes: USNM; 20979 (4)].

Distribution: northwestern Atlantic from Chesapeake Bay south to Florida; northern Gulf of Mexico.

Diplodus hottentotus (Smith, 1844)

Sargus hottentotus Smith, 1844: unpaginated, Pl. 23, Fig. 1 (SE coast of South Africa; holotype: BMNH 1845.7.3.51).

Distribution: South Africa.

Diplodus kotschyi (Steindachner ,1876)

Sargus kotschyi Steindachner, 1876: 203 [Persian Gulf; (Madagascar); syntypes: NMW 82859 (1)].

Distribution: Persian Gulf and Oman east to India.

Diplodus levantinus new species

Distribution: Israel, eastern Mediterranean Sea.

Diplodus lineatus (Valenciennes in Cuvier and Valenciennes, 1830)

Sargus lineatus Valenciennes in Cuvier and Valenciennes, 1830: 59 (no locality; holotype: MNHN A-8102).

Diplodus sargus insularum Cadenat, 1964: 962, Figs 5, 12, 24 [Cape Verde Islands; syntypes: MNHN 1964-0575-0578 (4), 1971-0002 (1)].

Distribution: Cape Verde Islands.

Diplodus noct (Valenciennes [ex Ehrenberg] in Cuvier and Valenciennes, 1830)

Sargus noct Valenciennes [ex Ehrenberg] in Cuvier and Valenciennes, 1830: 51 [Suez, Gulf of Suez, Egypt, Red Sea; syntypes: MNHN 8564 (1), 85658566 (2), 8575 (1)].

Distribution: Red Sea.

Diplodus omanensis Bauchot and Bianchi, 1984

Diplodus cervinus omanensis Bauchot and Bianchi, 1984: 103, Fig. A (Kuria Maria Bay, Oman, Arabian Sea; holotype: MNHN 1984-0358).

Distribution: northwestern Indian Ocean: Oman and Pakistan.

Diplodus prayensis Cadenat, 1964

Diplodus prayensis Cadenat, 1964: 955, 965, Figs 8, 14, 20 (Port of Praia, Sao Tiago Island, Cape Verde Islands; holotype: MNHN 1964-0579).

Distribution: Cape Verde Islands.

Diplodus puntazzo (Walbaum [ex Cetti], 1792)

Sparus puntazzo Cetti, 1777: 115 (Sardinia, Italy; no types known; not available, used as vernacular name only).

Sparus puntazzo Walbaum [ex Cetti], 1792: 282 (Sar- 
dinia, Italy; no types known; based on Cetti 1777).

Sparus acutirostris Delaroche, 1809: 348, Pl. 24, Fig. 12 (Ibiza, Balearic Islands, Spain, western Mediterranean Sea; holotype: MNHN A-8101).

Sparus oxyrhynchus Nardo, 1827: 31, 38 (No. 118) (Adriatic Sea; no types known).

Charax puntazzo var. ponticus Nordmann, 1840: 387, pl. 4, Fig. 2 (Sevastopol, Crimea, Ukraine, Black Sea; no types known).

Puntazzo annularis Bleeker, 1876: 284 (Mediterranean Sea; no types known; unneeded new name for Charax puntazzo of Cuvier and Valenciennes, =Sparus puntazzo Walbaum, 1792).

Distribution: Mediterranean Sea, Black Sea; eastern Atlantic from Sierra Leone north to southern Bay of Biscay, including Cape Verde and Canary islands.

Diplodus sargus (Linnaeus, 1758)

Sparus lineis transversis varius, macula nigra insigni ad caudam Artedi 1738a: 37, No. 13 (based on Artedi 1738b, No. 58; Sargus of authors).

Sparus lineis transversis varius, macula nigra insigni ad caudam Artedi 1738b: 58, No. 2 (Greece, France, Italy, Venice; based on O'Sargos of Aristoteles, Aelianus, Oppianus and Atheneus; Sargus of Ennius, Ovidius, Plinius, Juvenal, Bellonius, Rondeletius, Salviani, Gesner, Aldrovandius, Jonston, Charleton, Willughby and Rajus).

Sparus sargus Linnaeus, 1758: 278 (in M. infero, Adriatic Sea; no types known; based on 'Art. gen. 37, syn. 58, Sparus lineis transversis varius ...).

Sparus cinctus Walbaum, 1792: 282 (Marseille, France; no types known; based on Sparus sp., 'Sparus fascia subcaudali ...' of Brünnich 1768: 39, No. 58).

Sargus raucus Geoffroy Saint-Hilaire 1809: Pl. 18, Fig. 1 (Alexandria, Egypt; neotype: HUJ 6047, as designated above.)

Sparus sargius: Rafinesque, 1810a: 24, No. 151 (Messina, Sicily, Italy).

Sparus varatulus Rafinesque, 1810b: 48 (Sicily, Italy; no types known).

Sargus rondeletii Valenciennes in Cuvier and Valenciennes, 1830: 14, pl. 141 [Naples, Italy; Marseille and Toulon, France; Malta; Alexandria, Egypt; Bizerte, Tunisia; syntypes: MNHN 8529-8530 (2), 8602 (1), A.8098 (1)].

Sargus vetula Valenciennes in Cuvier and Valenciennes, 1830: 48 [Martigues, France; Naples, Italy; syntypes: MNHN 8543 (2), 8544 (1)].

Diplodus sargus typicus Cadenat, 1964: 960 (part: Mediterranean Sea).

Distribution: Mediterranean Sea (except Israel), Black Sea.

Diplodus striatus (Bliss 1883)

Sargus striatus Bliss, 1883: 50 (Mauritius; holotype: MCZ 5731).

Distribution: southwestern Indian Ocean: Mauritius, Rodrigues.

Diplodus vulgaris (Geoffroy Saint-Hilaire, 1817)

Sargus noster primus ... Aldrovandi, 1638: Fig. [p. 174].
Sargus vulgaris Geoffroy Saint-Hilaire, 1817: 342, Pl. 18, Fig. 2 (Alexandria, Egypt; no types known).

Sparus aldrovandi Nardo, 1827: 21, 38 (no. 117) (Adriatic Sea; no types known; based on Aldrovandi 1638, p. 174).

Sargus salviani Valenciennes in Cuvier and Valenciennes, 1830: 28 [Mediterranean Sea; part, based on Sargus of Salviani 1558, p. 179; Aldrovandi 1638, p. 174; Sargus vulgaris of Geoffroy Saint-Hilaire 1817, pl. 18, Fig. 2; syntypes: MNHN 8533 (1), 8534 (1), 8549 (2)].

Distribution: Mediterranean Sea, southwestern Black Sea; eastern Atlantic from Canary Islands and Madeira north to Brittany (France); Angola.

\section{Key to eastern Atlantic and Mediterranean species of the Diplodus sargus group}

1- Each side of upper jaw with a total of 28-43 molariform teeth in 4-5 principal rows; each side of lower jaw with a total of 20-31 molariform teeth in 3-6 principal rows; molariform teeth in upper jaw reaching to base of incisors ....

- Each side of upper jaw with a total of 8-19 molariform teeth in 1-3 principal rows; each side of lower jaw with a total of 3-14 molariform teeth in 2-3 principal rows; molariform teeth in upper jaw not reaching to base of incisors, separated by a distance of at least 2 lengths of the largest molariform tooth

2- Each side of upper jaw with a total of 28-32 molariform teeth Diplodus sargus

- Each side of upper jaw with a total of 36-43 molariform teeth 3

3- Each side of lower jaw with a total of 27-31 molariform teeth in 4-6 principal rows; sides of body in large adults with alternating broad and narrow vertical dark bars, in addition to dark blotch on caudal peduncle..... Diplodus cadenati

- Each side of lower jaw with a total of 19-22 molariform teeth in 3-4 principal rows; sides of body in large adults without vertical dark streaks, in smaller adults with about 9 vertical dark bars of even width, in addition to dark blotch on caudal peduncle......... Diplodus capensis

4- Each side of upper jaw with a total of 8-10 molariform teeth in 1-2 principal rows; each side of lower jaw with a total of 3-4 molariform teeth in 2 principal rows; molariform teeth in lower jaw not reaching to base of incisors, separated by a distance of at least 2 lengths of the largest molariform tooth; sides of body with 4 broad and one narrow vertical dark bars, in addition to dark blotch on dorsal half of caudal peduncle .................... Diplodus lineatus

- Each side of upper jaw with a total of 16-19 molariform teeth in 2-3 principal rows; each side of lower jaw with a total of 12-14 molariform teeth in 2-3 principal rows; molariform teeth in lower jaw nearly reaching to base of incisors; sides of body 
with about 8 narrow vertical dark bars of even width, in addition to dark blotch nearly all across caudal peduncle Diplodus levantinus n. sp.

\section{ACKNOWLEDGEMENTS}

We are grateful to Dr. I. Aizenberg (Veterinary Teaching Hospital, Koret School of Veterinary Medicine, Hebrew University of Jerusalem, Israel) for providing a radiograph of the holotype of Diplodus levantinus n. sp. We thank Rui Freitas (Universidade de Cabo Verde), who assisted in acquiring endemic Diplodus species from the Cape Verde Islands. We are grateful to Alberto Brito (Universidad de La Laguna, Tenerife, Spain) for his hospitality, and for collecting D. cadenati from Tenerife and Senegal. Dominique Didier (ANSP, Philadelphia), Marie-Louise Bauchot and Martine Desoutter (MNHN, Paris), Giuliano Doria (MSNG, Genoa), Jeffrey T. Williams (USNM, Washington DC) and Peter Bartsch (ZMB, Berlin) gave access to materials in their care.

\section{REFERENCES}

Aldrovandi U. 1638. De piscibus libri V et de cetis lib. unus. I. B. Bellagamba, Bononiae [Bologna]: 6 [unnumbered] + (372)732 +27 [unnumbered] pp.

Artedi P. 1738a. Genera piscium. In quibus systema totum ichthyologiæ proponitus cum classibus, ordinibus, generum characteribus, specierum differentiis, observationibus plurimis. Redactis speciebus 242 ad genera 52. Ichthyologiæ pars 3. Conradus Wishoff, Lugduni Batavorum (Leiden), 84 + ii pp.

Artedi P. 1738b. Synonymia nominum piscium fere omnium; in qua recensio fit nominum piscium, omnium facile authorum, qui undam de piscibus scripsere: uti Graecorum, Romanorum, Barbarorum, nec non omnium insequentium ichthyologorum, una cum nominibus inquilinis variarum nationum. Ichthyologiae pars 4. Conradus Wishoff, Lugduni Batavorum (Leiden), $\mathrm{i}+118+$ xxi pp.

Bargelloni L., Alarcon J.A., Alvarez M.C., et al. 2005. The AtlanticMediterranean transition: discordant genetic patterns in two seabream species, Diplodus puntazzo (Cetti) and Diplodus sargus (L.). Molec. Phylogen. Evol. 36: 523-535. http://dx.doi.org/10.1016/j.ympev.2005.04.017

Bauchot M.-L., Bianchi G. 1984. Diplodus cervinus omanensis, nouvelle sous-espèce de Diplodus cervinus (Lowe, 1841), capturée en mer d'Arabie (Pisces, Perciformes, Sparidae). Cybium 8(3): 103-105.

Bauchot M.-L., Daget J. 1971. Les Diplodus (Pisces, Sparidae) du groupe cervinus-fasciatus. Cah. ORSTOM, Sér. Océanogr. 9(3): 319-338

Bauchot M.-L., Daget J. 1972. Catalogue critique des types de poissons du Muséum national d'Histoire naturelle. (Suite.) (Famille des Sparidae). Bull. Mus. Nat. Hist. Nat. (Sér. 3: Zool.) 24(Zool. 18): 33-100.

Bauchot M.-L., Daget J., Bauchot R. 1990. L’ichtyologie en France au début du XIXe siècle. L'Histoire naturelle des poissons de Cuvier et Valenciennes. Bull. Mus. Nat. Hist. Nat. A (Zool.) (4)12(1), Suppl.: 1-142.

Bean T.H. 1878. Description of a new sparoid fish, Sargus holbrookii, from Savannah Bank. Proc. U. S. Nat. Mus. 1(28): 198-200.

Ben-Tuvia A. 1953a. Mediterranean fishes of Israel. Sea Fish. Res. Stat., Bull. 8: 1-40.

Ben-Tuvia A. 1953b. Fishes caught off Caesarea, on the Mediterranean coast of Israel. Res. Counc. Isr. Bull. (B, Zool.) (4): 439-440.

Ben-Tuvia A. 1971. Revised list of the Mediterranean fishes of Israel. Isr. J. Zool. 20: 1-39.

Bleeker P. 1876. Systema Percarum revisum. Pars Ia. Percae. Arch. Néerl. Sci. Exact. Nat. 11: 247-288.

Bliss R. 1883. Descriptions of new species of Mauritian fishes. Trans. Roy. Soc. Arts Sci. Mauritius (N. S.) 13: 45-63.
Bodenheimer F.S. 1935. Animal life of our marine shores. In: Bodenheimer F.S. (ed.): Animal life in Palestine. L. Mayer, Jerusalem, pp. 451-472, pls. 65-70.

Bodenheimer F.S. 1937. Pisces. In: Prodromus faunae Palestinae. Mém. Inst. Égypte 1937: 271-275.

Brünnich M.T. 1768. Ichthyologia Massiliensis, sistens piscium descriptiones eorumque apud incolas nomina. Accedunt Spolia Maris Adriatici. Roth, Hafniae et Lipsiae, xvi+110 pp. http://dx.doi.org/10.5962/bhl.title.5782

Cadenat J. 1964. Notes d'ichtyologie ouest-africaine. XLII. Les "Sars" des genres Puntazzo et Diplodus des eaux tropicales ouest-africaines. Bull. Inst. Fr. Afr. Noire, Sér. A Sci. Nat. 26(3): 944-988.

Caldwell D.K. 1965. A new sparid fish of the genus Diplodus from Bermuda. Fieldiana Zool. 44(23): 217-225.

Casu M., Lai T., Curini-Galletti M., et al. 2009. Identification of Mediterranean Diplodus spp. and Dentex dentex (Sparidae) by means of DNA Inter-Simple Sequence Repeat (ISSR) markers. J. Exp. Mar. Biol. Ecol. 368: 147-152. http://dx.doi.org/10.1016/j.jembe.2008.09.021

Cetti F. 1777. Anfibi e pesci di Sardegna. In: Piatoli G. (ed.): Storia naturale di Sardegna, v. 3. G. Piattoli, Sassari, viii (unnumbered) +208 pp., 5 pls http://dx.doi.org/10.5962/bhl.title.5783

Cuvier G., Valenciennes A. 1830. Histoire naturelle des poissons. Tome Sixième. Livre sixième. Partie I. Des Sparoïdes; Partie II. Des Ménides. Paris: xxiv + 6 +559 pp., pls. 141-169.

Delaroche F.E. 1809. Suite du mémoire sur les espèces de poissons observées à Iviça. Observations sur quelques-uns des poissons indiqués dans le précédent tableau et descriptions des espèces nouvelles ou peu connues. Ann. Mus. Hist. Nat. Paris 13: 313361 , pls. 20-25.

Domingues V.S., Santos R.S., Brito A., et al. 2007. Mitochondrial and nuclear markers reveal isolation by distance and effects of Pleistocene glaciations in the northeastern Atlantic and Mediterranean populations of the white seabream (Diplodus sargus, L.). J. Exp. Mar. Biol. Ecol. 346: 102-113. http://dx.doi.org/10.1016/j.jembe.2007.03.002

Eschmeyer W.N., Fricke R. (eds). 2015. Catalog of fishes, electronic version (2 Oct. 2015). California Academy of Sciences, San Francisco. Accessed on 28 Oct. 2015. http://research.calacademy.org/research/Ichthyology/Catalog/ fishcatmain.asp

Fischer W., Schneider M., Bauchot M.-L. (eds) 1987. Fiches FAO d'identification des espèces pour les besoins de la pêche. Méditerranée et mer Noire. Zone de pêche 37. Révision 1. Volume II Vertébrés. FAO, Rome.

Fricke R. (ed.) 2015. References in the Catalog of fishes, electronic version (2 Oct. 2015). California Academy of Sciences, San Francisco. Accessed on 28 Oct. 2015. http://research.calacademy.org/research/Ichthyology/Catalog/ fishcatmain.asp

Fricke R., Eschmeyer W.N. 2015. A guide to fish collections in the Catalog of fishes. Online version, updated 2 Oct. 2015. California Academy of Sciences, San Francisco. Accessed on 28 Oct. 2015.

http://research.calacademy.org/research/Ichthyology/Catalog/ collections.asp

Fricke R., Bilecenoglu M., Sari H.M. 2007. Annotated checklist of fish and lamprey species (Gnathostomata and Petromyzontomorphi) of Turkey, including a Red List of threatened and declining species. Stuttg. Beitr. Naturk., Ser. A (Biol.) 706: 1-174.

Geoffroy Saint-Hilaire E. 1809. Poissons du Nil, de la mer Rouge et de la Méditerranée. In: Description de l'Egypte ou recueil des observations et des recherches qui ont été faites en Égypte pendant l'expedition de l'Armée français, publié par les ordres de sa Majesté-L'Empereur Napoléon le Grand, v. 1 (part 1). Imprimerie Impériale, Paris: 1-52 [141-338], Poissons Pls. 1-17.

Geoffroy Saint-Hilaire E. 1817. Poissons du Nil, de la mer Rouge et de la Méditerranée. In: Description de l'Egypte ou recueil des observations et des recherches qui ont été faites en Égypte pendant l'expedition de l'Armée français, publié par les ordres de sa Majesté-L'Empereur Napoléon le Grand. Tome 1, (pt. 1). Imprimerie Impériale, Paris, pls. 18-27.

Geoffroy Saint-Hilaire I. 1827. Poissons du Nil, de la mer Rouge et de la Méditerranée. In: Description de l'Egypte ou recueil des observations et des recherches qui ont été faites en Égypte pendant l'expedition de l'Armée français, publié par les ordres de sa Majesté-L'Empereur Napoléon le Grand. Imprimerie Impériale, Paris: pp. 311-343. 
Golani D. 1996. The marine ichthyofauna of the eastern Levant history, inventory, and characterization. Isr. J. Zool. 42: 15-55.

Golani D. 2005. Checklist of the Mediterranean fishes of Israel. Zootaxa 947: 1-90.

Golani D. 2006. Handbook of the fishes of Israel. 3rd ed. [In Hebrew.] Keter, Jerusalem, 269 pp.

Golani D., Öztürk B., Başusta N. 2006. Fishes of the eastern Mediterranean. Turkish Marine Research Foundation, Istanbul, 259 pp.

González-Wangüemert M., Pérez-Ruzafa Á., García-Charton J.A., et al. 2006. Genetic differentiation and gene flow of two Sparidae subspecies, Diplodus sargus sargus and Diplodus sargus cadenati in Atlantic and south-west Mediterranean populations. Biol. J. Linn. Soc. 89 (4): 705-717. http://dx.doi.org/10.1111/j.1095-8312.2006.00706.x

Hornell J. 1935. Report on the fisheries of Palestine. Government of Palestine, Jerusalem, $106 \mathrm{pp}$.

Lacepède B.G.E. 1802. Histoire naturelle des poissons, v. 4. Plassan, Paris: i-xliv + 1-728, pls. 1-16.

Larrañaga D.A. 1923. Escritos de Don Dámaso Antonio Larrañaga. Los Publica el Instituto Histórico y Geográphico del Uruguay, v. 2. Edición Nacional, Montevideo: 512 pp.

Liebman E. 1934. Annexe II. Contributions to the knowledge of Palestine sea fishes. Rapp. Proc.-Verb. Réun., Cons. Perm. Int. Expl. Mer 8: 317-327.

Linnaeus C. 1758. Systema naturae per regna tria naturae, secundum classes, ordines, genera, species, cum characteribus, differentiis, synonymis, locis. Tomus I. Editio decima, reformata. Laurentius Salvius, Holmiae, ii + 824 pp.

Lowe R.T. 1838. A synopsis of the fishes of Madeira; with the principal synonyms, Portuguese names, and characters of the new genera and species. Trans. Zool. Soc. London 2(pt 3, art. 14): 173-200.

Loy A., Bertelletti M., Costa C., et al. 2001. Shape changes and growth trajectories in the early stages of three species of the genus Diplodus (Perciformes, Sparidae). J. Morph. 250 (1): 24-33. http://dx.doi.org/10.1002/jmor.1056

Man-Wai R., Quignard J.-P. 1982. Les sars Diplodus sargus (Linné, 1758) du Golfe du Lion: Croissance et caractéristiques des débarquements aus criées de Sète et du Grau-du-Roi. Rev. Trav. Inst. Pêches Marit. 46(3): 173-194.

Nardo G.D. 1827. Prodromus observationum et disquisitionum Adriaticae ichthyologiae. Giorn. Fis., Chim. Stor. Nat., Med, Arti (Ser. 2) Dec. II, 10: 22-40.

Nordmann A. von 1840. Prodrome de la ichthyologie pontique. In: Démidoff A. de (ed.): Voyage dans la Russie méridionale et la Crimée. V. 3. E. Bourdin et Cie., Paris, pp. 353-635, 748-755, Pisces pls. 1-32. [Text appeared in 1840, atlas with plates in 1842.]

Pallas P.S. 1814. Zoographia Rosso-Asiatica, sistens omnium animalium in extenso Imperio Rossico et adjacentibus maribus observatorum recensionem, domicilia, mores et descriptiones anatomen atque icones plurimorum, vol. 3. Petropoli, vii +428 pp.+ index (cxxv pp.), pls. 1, 13, 14, 15, 20 and 21. [Date of publication for vol. 3 fixed in Opinion 212, International Commission on Zoological Nomenclature as 1814.]

Paz R. de la. 1975. Systématique et phylogenèse des Sparidae du genre Diplodus Raf., (Pisces, Teleostei). Trav. Docum. ORSTOM 45: 1-96.

Paz R. de la. 1982. Note critique sur la nomenclature des Diplodus du groupe sargus (Pisces, Sparidae). Bull. Mus. Nat. Hist. Nat. (4)3(A3) (for 1981): 931-934.

Paz R. de la., Bauchot M.-L., Daget J. 1974. Les Diplodus (Perciformes, Sparidae) du groupe sargus: systématique et phylogénie. Ichthyologia 5(1) (for 1973): 113-128.

Poey F. 1860. Memorias sobra la historia natural de la Isla de Cuba, acompañadas de sumarios Latinos y extractos en Francés. Tomo 2. La Habana, 442 pp., pls. 1-19. [Published in 1858-1861; publication dates: pp. 1-96 (1858), 97-336 (1860), 337-442, (1861)].

Quéro J.-C., Guéguen J. 1978. Données sur la faune ichthyologique du Golfe de Gascogne. 1. Répartition des Diplodus (Sparidae, Perciformes) et remarques sur leurs stades juvéniles. Cybium 3(3): 82-94.

Rafinesque C.S. 1810a. Indice d'ittiologia siciliana; ossia, catalogo metodico dei nomi latini, italiani, e siciliani dei pesci, che si rinvengono in Sicilia disposti secondo un metodo naturale e seguito da un appendice che contiene la descrizione de alcuni nuovi pesci siciliani. G. del Nobolo, Messina, 70 pp., pls. 1-2.

Rafinesque C.S. 1810b. Caratteri di alcuni nuovi generi e nuove specie di animali e piante della Sicilia, con varie osservazioni sopra i medisimi. Sanfilippo, Palermo. (Part 1 involves fishes, pp. [i-iv] 3-69 [70 blank], Part 2 with slightly different title, pp. ia-iva + 71-105 [106 blank]). Pls. 1-20. http://dx.doi.org/10.5962/bhl.title.104418

Salviani I. 1558. Aquatilium animalium historiae liber primus. Romae, $471 \mathrm{pp}$.

Sauvage H.-E. 1879. Description de quelques poissons d'espèces nouvelles de la collection du Muséum d'histoire naturelle. Bull. Soc. Philom. Paris (Sér. 7) 3: 204-209.

Smith A. 1844. Pisces. In: Illustrations of the zoology of South Africa; consisting chiefly of figures and descriptions of the objects of natural history collected during an expedition into the interior of South Africa in 1834-36, vol. 4. Smith, Elder and Co., London: 77 unnumb. pp, accompanying pls. 1-31.

Smith C.L., Bailey R.M. 1961. Evolution of the dorsal-fin supports of percoid fishes. Pap. Michigan Acad. Sci., Arts Lett. 46 (for 1960): 345-363, pl. 1 .

Steindachner F. 1876. Ichthyologische Beiträge (V). Sitzungsber. K. Akad. Wiss., Math.-Naturw. Cl. 74(1. Abth.): 49-240, pls. $1-15$.

Steindachner F. 1882. Beiträge zur Kenntniss der Fische Afrika's (II) und Beschreibung einer neuen Paraphoxinusart aus den unterirdischen Gewässern in der Herzegowina. Anz. K. Akad. Wiss. Wien 19(5): 41-43.

Steinitz W. 1927. Beiträge zur Kenntnis der Küstenfauna Palästinas. Erster Teil. Pubbl. Staz. Zool. Napoli 8: 311-353.

Summerer M., Hanel R., Sturmbauer C. 2001. Mitochondrial phylogeny and biogeographic affinities of sea breams of the genus Diplodus (Sparidae). J. Fish Biol. 59(6): 1638-1652. http://dx.doi.org/10.1111/j.1095-8649.2001.tb00227.x

Walbaum J.J. 1792. Petri Artedi sueci genera piscium. In quibus systema totum ichthyologiae proponitur cum classibus, ordinibus, generum characteribus, specierum differentiis, observationibus plurimis. Redactis speciebus 242 ad genera 52. Ichthyologiae pars III. Ant. Ferdin. Rose, Grypeswaldiae [Greifswald], [viii] +723 pp., pls. $1-3$

Whitehead P.J.P., Bauchot M.-L., Hureau J.-C., et al. 1986. Fishes of the North-eastern Atlantic and the Mediterranean. Vol. II. UNESCO, Paris, pp. 517-1007. 